\title{
DOS ALTERNATIVAS CULTURALES ANTE LA CRISIS ARGENTINA: LA MÚSICA DE LOS EXCLUIDOS Y EL TEATRO "BARRIAL" DE LA CLASE MEDIA.
}

\author{
Manuela Fernández Mayo \\ UNIVERSIDAD DE CÁDIZ
}

\begin{abstract}
RESUMEN
Argentina ha visto surgir una serie de manifestaciones artísticas y culturales unidas al contexto de la crisis, de las cuales destacamos en el panorama musical, la aparición y desarrollo de la cumbia villera, un subgénero musical que alberga la identidad del nuevo pobre urbano argentino, una música que se ha impuesto dentro del panorama de la música tropical como una reivindicación del estilo de vida de los habitantes de las villas miserias. Implica un discurso que manifiesta la discriminación, en tanto marginalidad y exclusión social a la vez. Por su parte, el teatro barrial ha aglutinado a los sectores sociales medios y su singularidad reside en que aquí los artistas, son los propios vecinos. El teatro comunitario parte de la idea de que el arte es un agente de transformación social y responde a un intento de recuperar la identidad cultural del país empezando por el barrio y el entorno, pero también se erige como un acto de resistencia cultural frente a un mundo globalizado, que tiende a borrar las diferencias culturales.
\end{abstract}

Palabras Clave: Argentina, crisis, cumbia villera, teatro barrial o comunitario.

\section{ABSTRACT}

Argentinian culture has been a witness - together with the economic crisis- of a group of artistic and cultural signs from which we, in the musical context- emphasize the beginning and development of the "cumbia villera", a musical subgenre which shows the identity of the new urban poor man in Argentina, a kind of music that has prevailed within the tropical one as a claim to life style of inhabitants from poor villages, It refers to both, a marginal and social discrimination. On the other hand, The theater claypit has agglutinated to the average social sectors and its singularity resides in which here the artists, they are the own neighbors. The communitarian theater part of the idea that the art is an agent of social transformation and it responds to an attempt 
to recover the cultural identity of the country beginning by the district and the surroundings, but also front to a globalizado world is elevated like an act of cultural resistance, that it tends to erase the cultural differences.

Key Words: Argentina- Crisis- "cumbia villera"- communitarian theater or claypit.

En el doloroso escenario social del nuevo milenio, la siempre fecunda cultura Argentina, ha visto emerger o consolidarse, una serie de nuevos planteamientos artísticos inextricablemente unidos al contexto de la crisis, de los cuales destacamos en el panorama musical ${ }^{1}$, la aparición y desarrollo de la cumbia villera; en las artes escénicas, la maduración y difusión del teatro barrial o comunitario; y en el campo de la imagen, de un lado, el desarrollo cuantitativo y cualitativo del género documental y, la eclosión del "nuevo cine argentino"; el otro tema, por fortuna más gratificante, por el que Argentina atrae las miradas del mundo en los últimos años y cuyo análisis demanda por sí sólo un estudio independiente. El presente artículo estará dedicado al análisis de la cumbia villera y del teatro barrial o comunitario, como las expresiones culturales cuya eclosión guarda un paralelismo con el desarrollo de la crisis argentina.

\section{LA CUMBIA VILLERA}

La cumbia villera es el subgénero musical que alberga la identidad del nuevo pobre urbano argentino, una música que se ha impuesto dentro del panorama de la música tropical como una reivindicación del estilo de vida de los habitantes de las villas de emergencia y en sus canciones se hace alusión al consumo de drogas, a la relación de los delincuentes con la policía y demás situaciones violentas. Nace en los guetos de la ciudad, entre chapas, charcos y cartones. No es un fenómeno musical o poético, sino que a menudo es descarnada y sin eufemismos.

Alcanzó notoriedad a fines de la década de los ' 90 y se abrió paso, a través de la televisión y la radio, desde las "bailantas" de la periferia de Buenos Aires, hasta las casas y boliches propios de la clase media. Ese consumo policlasista se ha producido por motivos diferentes. En los sectores medios, se escucha como un género novedoso pero fundamentalmente, por su carácter festivo y trasgresor.

Para los sectores populares, en cambio, la cumbia villera muestra un estilo de vida y una forma original de digerir una realidad que en gran parte les representa. En este sentido, dicho género es una expresión cultural, esto es, la manifestación pública y colectiva predominante, de un sector social determinado. La cumbia villera es una de las expresiones culturales que un sector social (adolescentes y jóvenes, en general pobres, y en muchos casos en conflicto con la ley) ha elegido como medio privilegiado para hacer pública su comprensión de la realidad ${ }^{3}$.

\footnotetext{
Conviven en el país dos géneros musicales típicos: el tango, representativo de lo porteño, símbolo musical de los argentinos en el extranjero. Es una música de culto que tiene fieles seguidores, aunque no sea escuchada habitualmente por el gran público. El folklore, posee variados ritmos y estilos de acuerdo a las diferentes regiones del interior del país y entre sus exponentes destacan: Mercedes Sosa, Horacio Guarany, Los Nocheros, Teresa Parodi, Soledad, entre otros. El cuarteto y la cumbia, originados en la provincia de Córdoba, comenzaron a ocupar un espacio dentro de la música nacional. Fuera del ámbito de los géneros tradicionales, encontramos al rock y al pop porteños, representado por los ya emblemáticos Charly García, Luis Alberto Spinetta, Fito Páez , Andrés Calamaro y también por Gustavo Ceratti, Vicentino, Diego Torres, entre otros.

2 Bailanta = salón de baile popular donde actúan músicos en vivo, que ejecutan por lo general música tropical similar a la salsa, "cumbia" o "cuarteto". Boliche = salón de baile o discoteca, pero también se emplea para referirse a un bar, restaurante, cafetería, fonda.

3 MÍGUEZ, Daniel: Los pibes chorros. Estigma y marginación. Ed. Capital Intelectual. Buenos Aires, 2004, pág.74.
} 
Las letras, estilo musical y la estética (la forma de vestirse, bailar, moverse) de los grupos cumbieros, expresan muy claramente esa cultura y generan una clara identificación entre quienes la comparten.

\title{
A. Origen y desarrollo de la cumbia villera.
}

Colombia es el lugar de origen de la cumbia, una forma musical del litoral colombiano, resultado de un proceso de mestizaje y sincretismo que a través de migraciones rurales se fue extendiendo por el continente y según el Compendio general de folklore colombiano se define como:

\begin{abstract}
"la tonada musical y su coreografía respectiva que designa el aire típico y su correspondiente danza-tipo de la zona del litoral Atlántico (de Colombia). Se puede sondear el nombre de cumbia, como pariente lejano del vocablo cubano "cumbancha" -(jolgorio, parranda)" 4
\end{abstract}

En la Argentina, esta música tiene características diferentes y en los últimos años toma contacto desde el norte con la cumbia andina boliviana, a través de las migraciones rurales de bolivianos, paraguayos y peruanos. En 1930 llega a Buenos Aires el músico colombiano Efraín Orozco, quien fusionó la música colombiana con la de otros países, creando una orquesta de concepción moderna - tipo jazz band - con arreglos atrevidos para su época (parangonándose con lo que hacía Javier Cugat en Estados Unidos). Los críticos de la época decían que se trataba de una cumbia "lavada", que no era pura, sino supeditada a las exigencias comerciales, no obstante es indudable su papel como introductor del género, ya que sobre 1945 estaría consolidada ${ }^{5}$.

Durante la década del '50 y comienzos de los ' 60 , surgió el fenómeno del folklore criollo.

Paralelamente a las primeras corrientes de inmigración interna y auspiciada por la incipiente TV, se recreaban estas manifestaciones en "peñas" (fiestas y veladas en los clubes de barrio y sociedades de fomento) que afloraban en la capital cada fin de semana, atrayendo una gran concurrencia. Eran los "cabecitas negras" ("personas humildes procedentes de las provincias del interior, cuya piel contrastaba con los descendientes de europeos que habitaban Buenos Aires, y que cultivaban este tipo de música, entre otras costumbres) que vivían en las cercanías de la autopista Panamericana y Av. General Paz (arterias de acceso a la gran capital) y posteriormente, relacionado con las fiestas de carnaval apareció el término "bailanta":

"local de grandes dimensiones en el que la gente de condición modesta se divierte bailando danzas, principalmente tropicales ${ }^{6}$.

Eran lugares al aire libre que se adornaban con bombillas de colores, y donde un improvisado bar ofrecía vinos, caña y ginebra; muy distantes estos inicios de las monumentales construcciones actuales, con luces, robótica y sonidos espectaculares.

4 MORALES ABADÍA, Guillermo: Compendio general de folklore colombiano. Instituto Colombiano de Cultura, Bogotá, 1977, pág. 141 .

5 BARRAGÁN SANDI, Fernando: "La cumbia villera testimonio del joven urbano marginal ( censura y premiación)"en Anais do V Congresso Latinoamericano da Associação Internacional para o Estudo da Música Popular, Río de Janeiro, 2004 6 Definición procedente de GOBELLO, José y AMUCHÁSTEGUI, Irene: Vocabulario ideológico del lunfardo. Ed. Corregidor, Buenos Aires, 1998. pág 14. El diccionario de la Real Academia de la Lengua (XXI edición) define bailanta como "fiesta del pueblo en la que se baila". 
En los años '60 se comenzó a escindir las preferencias musicales en función de la clase social: obreros y trabajadores de bajos ingresos, frecuentemente provincianos, hacia la cumbia; jóvenes de clase media hacia el rock de importación, que venía impulsado por las multinacionales discográficas. Con el paso de los años la "bailanta" fue declinando, tendiéndose a nombrarla con el apelativo de "movida tropical" cuya única diferencia estribaba en la inclusión entre sus letras de la temática picaresca y de doble sentido.

La música "cuartetera" " nacida en la provincia de Córdoba, irrumpe en Buenos Aires con Miguelito Gelfo en abril de 1986; el Cuarteto Leo, el Cuarteto Berna, Carlitos Rolán y Carlos 'La Mona' Jiménez consolidan este desarrollo. Los solistas como Sebastián, Pocho 'la pantera', Ricki Maravilla, Badi, masifican el gusto por esta música, que encuentra su refrendo definitivo cuando la música tropical tiene su espacio en televisión, hasta entonces vetada para este género. Los registros de ventas de discos aumentaron considerablemente y la cumbia pasó a insertarse en los repertorios musicales de los sectores sociales más elevados y los balnearios veraniegos más selectos.

Cuando el menemismo triunfó apoyándose en los sectores más ricos y más pobres del electorado, los primeros abrieron medios de comunicación, discotecas y fiestas en el conurbano bonaerense a la cumbia. En la medida en que creció la desocupación y aumentó la organización y lucha del movimiento piquetero, las letras almibaradas de cumbia tradicional fueron perdiendo terreno.

El surgimiento del subgénero puede entenderse como una reacción ante la aceptación alcanzada por la cumbia a secas, en el gusto medio de la audiencia a lo largo de los noventa. Frente a los grandes valores de la vieja guardia (Ricky Maravilla, Gilda), al componente edulcorado de la cumbia romántica (Leo Mattioli, Los Mensajeros del Amor), a las combinaciones tropical-pop (grupos Sombras, Ráfaga) y al avance de la fiesta neocuartetera (Rodrigo, Walter Olmos) ${ }^{8}$, la cumbia villera vino a reflejar la aspereza de la vida en los márgenes del conurbano bonaerense, a la vez que otros productos culturales más o menos contemporáneos que pusieron el foco sobre los excluidos del sistema (la película Pizza, birra, faso o la serie televisiva Okupas $^{9}$ ), aunque tuvieron menos difusión y permanencia.

Recordemos que las villas -que es donde se gesta esta música- son lugares muy precarios, con calles de tierra trazadas desordenadamente por ellos mismos, con instalaciones incluso clandestinas de cables de electricidad, sin servicios básicos como agua potable o teléfonos, donde el colectivo o autobús no pasa con regularidad, y generalmente no se detiene cerca; donde la escuela ocupa más un lugar de contención que de formación y llegan a ser más fuertes los "lazos fraternales", la relación con el grupo y con los amigos, que con los padres o la familia, donde la desocupación es una constante y el tiempo se mide sólo por el presente y nunca por el futuro. Una zona del país donde la brecha entre pobres y ricos resulta abismal, donde la fortuna ajena parece al alcance de la mano: allí se da la maldita vecindad entre el hambre y la opulencia.

El epicentro de aparición de la cumbia villera, se ubica en la localidad de San Fernando distante $30 \mathrm{Km}$. de la Capital Federal; en la zona norte del conglomerado de partidos del conurbano bonaerense, llamado Gran Buenos Aires.

7 El cuarteto es una formación musical a modo de banda, que ejecutan composiciones alegres y muy apropiadas para bailar, similares a la salsa. Los "cuartetos" tienen no menos de 8 músicos y uno o varios cantantes. Es la música más popular en la provincia de Córdoba.

8 ANDRADE, Juan : "Cuando en la villa subieron el volumen” en Revista el Monitor, $\mathrm{n}^{\circ}$ 3, Ministerio de Educación, Ciencia y Tecnología, Buenos Aires, diciembre 2004, págs. 20-22.

9 Realizada con gran premura de medios (se rodó en $16 \mathrm{~mm}$ ), se considera aldabonazo de salida del nuevo cine argentino y la serie Okupas, de 11 capítulos dirigida por Bruno Stagnaro, fue lo más premiado de la cadena estatal Canal 7 en el 2000. Crueldad en excelentes diálogos, miedo al robo por primera vez, la venganza entre bandas, las drogas, la policía, los amigos, una ciudad que asfixia y parece no dar revancha, constituyeron la trama de la exitosa serie. 
Limita en su parte continental con los partidos de Tigre y San Isidro, con el río Luján y el río de la Plata. Esta localidad de 151.131 habitantes según el censo de 2001, es considerada Capital Nacional de la Náutica. Cuenta con un importante puerto deportivo y numerosos barrios cerrados o countries, en fuerte antagonismo con la presencia de villas miserias.

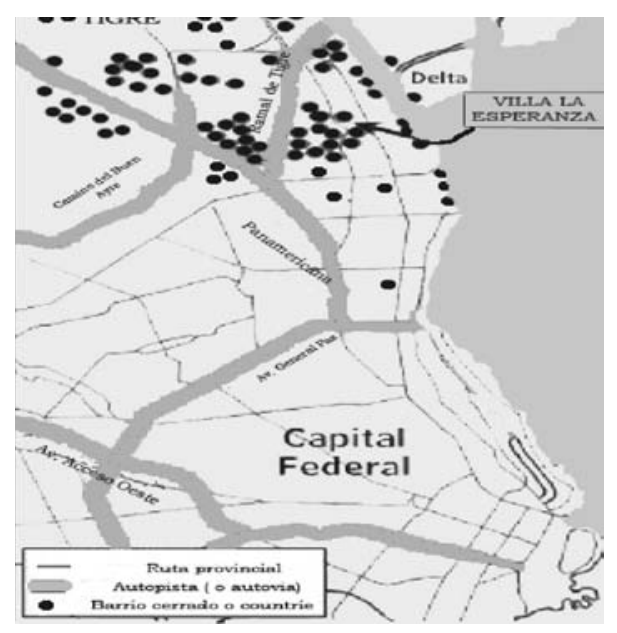

En el mapa se observa la importante concentración de barrios privados o countries en la zona norte del conurbano, especialmente en los partidos de Tigre, Pilar, San Fernando o San Isidro, bien conectados a las grandes vías de acceso a la Capital Federal. Paralelamente, al aumentar la pobreza, la indigencia y el desempleo dramáticamente en la última década, también proliferaron las villas miserias y asentamientos, ofreciendo a pocos metros de distancia una escandalosa imagen de la desigualdad social. Mapa de elaboración propia a partir de los datos de INDEC: ¿Qué es el Gran Buenos Aires? Ed. Instituto Nacional de Estadísticas y Censos, Buenos Aires, 2003. Mapa de elaboración propia.

La calle Uruguay actúa como lindero: de un lado, se extienden los elegantes barrios cerrados o countries con escuelas privadas de nombres en inglés y casetas de seguridad a la entrada de los mismos; del otro, las calles de tierra, un sinuoso sendero que divide las casas que poco a poco, van sustituyendo las chapas por ladrillos huecos. Son lugares donde los camiones repartidores, transitan sólo precedidos y seguidos por sendos autos de seguridad privada y donde los remiseros $^{10}$ no quieren entrar. Ahí se sitúan villas como la de San Francisco (donde vivía el Frente Vital), La Esperanza, San Cayetano, 25 de Mayo, Santa Rita, etc., ésta es la cuna de la cumbia villera.

La cumbia villera fusiona "cumbia histórica" -es decir, los ritmos clásicos de la música tropical- pero revierte sus temáticas: del amor traicionado y casi provinciano, a la vivencia de la marginalidad, la droga, el robo. La cumbia villera es música electrónica y su estructura musical es muy simple, salvo que se le agregue el baile, con un menor nivel de vocalización en comparación con la común música tropical o bailantera. Su sello distintivo lo encontró en el sonido estridente del teclado y una percusión machacona. Pero el estilo villero extendió sus dominios más allá de las notas. Y pronto apareció un vestuario que identificaba a sus seguidores: zapatillas de marca, pantalón de gimnasia, chamarra deportiva y gorra. Los músicos y el público comparten una misma estética, un mismo idioma y la fantasía de borrar los límites que separan a los que están arriba de los que están abajo del escenario ${ }^{11}$.

10 Remiseros : conductores de coches, cuyo servicio se contrata en un local o agencia de donde parten los coches, de forma que cuando llegan al destino preguntan por el coste del trayecto. Esta modalidad de servicio público de transporte se desarrolló de forma inusitada a partir de las privatizaciones de las empresas públicas en la década de los noventa.

11 SAI, Leonardo:”Youthanasia : ¿Divino tesoro o botín de guerra? “en Revista Lote, lo que nos tocó en suerte, Venado Tuerto (Santa Fe), año VIII, Febrero de 2005, nº 91, págs. 18-32. 
La mencionada cumbia villera pertenece a un ritual que legitima un modo de vida, la construcción de una realidad social que pone de manifiesto la discriminación, en tanto marginalidad y exclusión social simultáneamente. Es un elemento eficaz para la transmisión de una estética vinculada a los pobres, retratando sus vidas, su sexualidad y sus adicciones. A partir de la noción de identidad y desde ese discurso de características marginales excluyentes, del habitante de la 'villa' se desprende la oposición entre ellos y casi todo el contexto social que lo circunda.

El nacimiento de la cumbia villera se produce a fines de 1999 en la villa La Esperanza de San Fernando (Buenos Aires), cuando Pablo Lescano ${ }^{12}$ concebía los rasgos característicos y los temas del primer CD del grupo Flor de Piedra (nombre que alude a los cristales del clorhidrato de cocaína), llamado "la vanda (sic) más loca" “. Pablo Lescano quedó entre bambalinas, ya había alcanzado cierta cuota de éxito como compositor en otro grupo anterior, Amar Azul:

"Yo fui el productor, el que hizo todas las canciones, buscó a los músicos, les dije cómo se tenían que vestir, todo ${ }^{13}$,

Encontró un cantante ideal, "uno con cara de indio", y para sostener la credibilidad de lo que iba a cantar, lo fundamental: alguien que había pasado dos años de su vida preso. Se convirtió en un éxito, sobre todo el tema "Sos un botón", llegando a ser disco de platino ${ }^{14}$. En este tema aparecen trazados los grandes rasgos de la cumbia villera: la relación con las instituciones policiales, el fútbol, el alcohol, las drogas. Se inicia con la típica arenga jaleando al público y en el mismo se insulta a un "pibe" del barrio que se metió a policía:

¿Sufre, por hacerte policía;

No, no lo puedo creer/pues ya no sos el vago/ ya no sos el atorrantel al que los pibes lo llamaban "el picante" /ahora te llaman botón.

Ya no estás con tus amigos/y en la esquina te la dabas de polenta, de malevo y de matón ly sólo eras un botón /y sólo eras un botón

Vos, sos un botón/ nunca vi un policía tan amargo como vos (bis)

Para vos, Carlitos.../cuando ibas a la cancha /parabas con la hinchada/y tomabas vino blanco/y ahora patrullas la ciudad/ y vas a la cancha / vas en celular / y a tus amigos andas arrestando/sos el policía del comando/

Vos, sos un botón/ nunca vi un policía tan amargo como vos/ (bis) $)^{15}$

En abril del 2000 salió a la venta "Cumbia Villera", el primer CD de Yerba Brava, que le disputa a Dama \$ Grati\$ la primacía del género. "Yo soy el creador de todo", aseguraba Pablo

12 Pablo Lescano nacido en San Isidro en 1970, comenzó tocando el teclado desde los 13 años, como integrante del famoso "Amar Azul", un grupo de cumbia tradicional. Luego creo un estilo liderando el grupo "Flor de Piedra" y mas tarde organizó su grupo actual, "Dama\$ Grati\$”. Creador de su propio estilo musical cada vez mas imitado, la llamada "cumbia villera". Grabó la música de la película "El Bonaerense" de Pablo Trapero en 2002 .Llena cada lugar donde se presenta y ha actuado en varias ocasiones en Luna Park y hasta en el legendario templo del rock "Cemento". http://www.fantasticobailable.com/.

13 DILLON, Marta: "Lona, cartón y chapa "en Página 12, Buenos Aires, Sección Sociedad, 18 de mayo de 2001.

14 Los primeros éxitos fueron "Sos un botón", "La jarra loca" -himno al descontrol conseguido con una mezcla de Fernet con Coca y pastillas-, "La cumbia de los vagos" y "Patovica": vigilante que custodia la puerta en los salones de baile, gorila; individuo de complexión musculosa.

15 Todas las expresiones proceden del lunfardo: atorrante = vago, haragán; botón = agente de policía, soplón; darse de polenta $=$ formidable, optimo, excelente; malevo = malhechor, maleante, hombre matón y pendenciero que vivía en los arrabales de Buenos Aires; celular =coche patrulla; comando = unidad policial . 
Lescano: mientras Juan Carlos Ponce, líder de Yerba Brava, replicaba: "Nosotros somos los creadores de este estilo". ${ }^{16}$

Cuando Lescano compuso las canciones del segundo CD, "Más duros que nunca", ya tenía en mente su proyecto más personal, Dama $\$$ Grati\$. El debut del grupo en el que lo secunda su hermana Romina, fue en octubre del 2000. A partir de ese momento, surgieron nuevos grupos, además de Yerba Brava, Pibes Chorros, Altos Cumbieros, Meta Guacha, Supermerka2, Mala Fama, La Chala, Corre Guachín, Eh Guacho, Kalú, La Rama, Repiola, La Ihuana Mary, etc. ${ }^{17}$. Todos cultivadores de este estilo que sobre una fuerte base de cumbia colombiana, reconoce influencias del reagge, del rock y del rap (no sólo musicalmente sino también en la indumentaria). Los conjuntos suelen estar integrados por seis u ocho componentes que utilizan teclado eléctrico, instrumentos de pequeña percusión (güiros, timbales, conga, tumbadoras) guitarras, acordeón, etc. Todos estos grupos son producidos de forma empresarial, esto es, tienen dueños y los músicos son contratados (por ejemplo un componente del grupo"Meta Guacha" cobraba 30 pesos por actuación en 2001). Empresario, es el que pone el dinero para que graben, el que hace la difusión, compra la ropa, los instrumentos:

"Hay que poner entre 5 mil y 7 mil pesos para que empiece a funcionar" afirma Francisco Romano Labate, dueño del grupo Meta Guacha: "que quiere decir dale para adelante, en quichua, guacha quiere decir rebenque, pero es sólo un nombre comercial”, nombre que, al igual que el resto de los grupos, arengan entre tema y tema como una estrategia de marketing. "Los muchachos -todos aparecen con nombre de pila en el disco-viven en las villas. Yo que soy el compositor no, pero no hace falta: hace 13 años que estoy en la movida tropical y sé cómo vive esta gente $^{18}$."

En pleno despertar del nuevo milenio, la entrada en escena de la cumbia villera les otorgó a los sectores más postergados de la sociedad su credencial de ciudadanía mediática. Sus historias, sus códigos, sus costumbres, sus vicios, sus conflictos y, sobre todo, su particular lenguaje, irrumpieron sin pedir permiso en los hogares del país a través de portavoces como Damas Gratis, Flor de Piedra, Los Pibes Chorros, Yerba Brava y otros. Obviamente, el fenómeno tuvo su epicentro en las bailantas, las radios tropicales y los programas del sábado por la tarde ("Pasión de sábado", el célebre programa que dura cuatro horas de Daniel "la Tota" Santillán). Pero su impacto también se hizo sentir en los ciclos más populares de la tele, en las discotecas o boliches de moda y en las fiestas de los barrios más acomodados. A su paso, despertó tanto polémicas como adhesiones. En medio de la debacle (social, política, económica), jamás pasó inadvertida. No es casualidad que 2001, el peor año en la Historia Argentina reciente, haya coincidido con el de la explosión masiva de este fenómeno musical.

Pero las voces de preocupación por los contenidos y los mensajes de este subgénero musical comenzaron a hacerse sentir. La censura, vino de la mano del Comité Federal de Radiodifusión (COMFER). Este organismo tras elevar el informe denominado "Pautas de evaluación para los

16 Ibídem: DILlON, Marta: "Lona, cartón y chapa "en Página 12, Buenos Aires, Sección Sociedad, 18 de mayo de 2001. La disputa parece que viene del hecho de que Pablo Lescano hizo los temas pero no participó en Flor de Piedra, lo que sí haría en Dama\$ Grati\$, mientras que Yerba Brava alude que fueron los primeros que acuñaron el término "cumbia villera", ya que si el grupo de Lescano es anterior, éste no le daba dicha denominación. No obstante, el reconocimiento como fundador de este subgénero musical a Lescano es mayoritario.

$17 \quad \mathrm{Al}$ menos 26 grupos aparecen registrados en una de las páginas web más importante de cumbia villera. De ellos, entre los más importantes estarían: Damas Gratis, Yerba Brava, Pibes Chorros, Meta Guacha y Altos Cumbieros. http://www.fantasticobailable.com/cumbiavillera.html [diciembre, 2005].

18 Ibídem: DILLON, Marta: "Lona, cartón y chapa “en Página 12,.... 18 de mayo de 2001. 
contenidos de la Cumbia Villera" (julio de 2001), y alegando 'apología del delito' manifestó su preocupación por los contenidos de la cumbia villera y prohibió su acceso radial y televisivo:

“... como organismo de control de la programación audiovisual buscará PROTEGER la salud y formación de la audiencia en general y de los menores de edad en particular. Por ello decide no quedar al margen de una problemática tan actual y preocupante como lo es el uso, abuso y dependencia de sustancias psicoactivas. Tan actual que, la misma, es incorporada en los medios masivos de comunicación de distintos modos, siendo uno de ellos las composiciones de la denominada cumbia villera" 19

Logrando prohibir completamente su difusión dentro del espacio televisivo, por un período de 7 meses. A fines de 2002, Pablo Lescano - líder del grupo Dama \$ Grati\$, creador confeso de la cumbia villera, fue felicitado por Jorge Telerman, Secretario de Cultura de Buenos Aires, por haber recibido el Premio Clarín dentro del apartado "Revelación de la canción testimonial" (jurado conformado por periodistas de diversos medios y músicos). Como reacción a esto el sello Genoma, promocionó el CD "100\% Negro Cumbiero" con el slogan "Censurado en $T V$ " y su campaña llevó el titulo "entre el reconocimiento y la censura".

Paralelamente el género participó en las bandas sonoras de las exitosas películas argentinas "El bonaerense" y "El oso rojo" y en televisión, musicalizó la serie "Tumberos"y durante los años 2004 y 2005, la serie de televisión de mayor audiencia "Los Roldán", que se emite a diario por Telefé, producida por Ideas del Sur (Marcelo Tinelli), eligió a la música tropical como cortina de sus capítulos, pudiendo escucharse a Los Pibes Chorros , Grupo Aventura , Daniel Agostini, La Rama ,Los Pibex Ran y el Grupo Uno; y uno de los personajes de la serie es una "piba" cantante de cumbia villera, (encarnado por la actriz Lola Berthet), que desafina cumbias pegadizas y hasta el famoso travesti Florencia de la V, reitera hasta el cansancio el último hit " $L a$ gata" de estribillo contagioso y recurrente ${ }^{20}$.

La polémica sobre la cumbia villera, alcanzó el primer plano de la actualidad nacional cuando el 3 de agosto de 2004, el Jefe de Gabinete (y crítico musical) Alberto Fernández, en declaraciones a Radio Mitre, incluyó a la "cumbia villera" y la exaltación que esa música hace de la "acción delictiva", entre los factores que en la última década incidieron en la aumento de la inseguridad en Argentina, al igual que la pobreza y la marginalidad. Según Fernández:

"hace diez años no había un programa de televisión durante cinco horas difundiendo un tipo de música donde, en gran medida y por muchos momentos, se termina elogiando la acción delictiva, como es todo este fenómeno de la cumbia villera y este movimiento cultural entre comillas ${ }^{21}$ "

Al día siguiente y temiendo el coste electoral que las declaraciones del Jefe de Gabinete pudieran conllevar, el Presidente Kirchner recibió en audiencia al presentador televisivo del programa que difunde este género musical, Daniel Santillán, y desautorizó las palabras pronunciadas por el Jefe de Gobierno. El presentador Santillán, relató que en ese diálogo, el Presidente le dijo:

19 COMITÉ FEDERAL DE RADIODIFUSIÓN DE LA REPUBLICA ARGENTINA: Pautas de evaluación para los contenidos de la cumbia villera, Publicaciones Digitales COMFER, julio 2001. http://www.comfer.gov.ar/pdf/pubvenezuela/villera.pdf [diciembre, 2005].

20 Ibídem: BARRAGÁN SANDI, Fernando: "La cumbia villera testimonio del joven urbano marginal (censura y premiación)" en Anais do V Congresso Latinoamericano.

21 COLONNA, Lucas: "Según el gobierno la cumbia villera incide en la inseguridad" en La Nación, Buenos Aires, 4 de agosto de 2004 . 
"Yo banco la cumbia villera... ¿Quién no vio «Pasión de sábado»?” "Le pregunté al Presidente si nunca había bailado una cumbia. Y él me dijo que sí. Me contó que lo llamó su hijo Máximo y le preguntó qué quiso decir Alberto (el jefe de Gabinete). Y él lo retó”, completó el conductor $^{22}$

\section{B. La marginalidad y la exclusión como ejes de su temática.}

La cumbia villera se transformó en una vía de expresión musical de los sectores marginados y su fenómeno creció a la par de la pobreza. Se impuso dentro de la música tropical como una reivindicación y en sus canciones se hace alusión a esta realidad, reafirmando alegre y divertidamente la condición de marginalidad y exclusión en la que habitan.

La temática de la cumbia villera no representa su mayor originalidad, ya que se inscribe en una larga tradición de santificación de la "barbarie", que partiendo de lo gauchesco, pasa por el tango, el chamamé y el rock antes de desembocar en la cumbia. No es la primera y única vez donde el crimen, el "criminal" resulta santificado. Sin ir más lejos, el propio Martín Fierro era un prófugo de la ley; hay toda una rica tradición por medio de las historias de los gauchos celebres $^{23}$, bandoleros rescatados por el cancionero popular y en los repertorios del tango y del rock argentino las muestras son interminables.

Hasta llegar al horizonte de la crisis actual, para la cultura popular argentina el pobre se identificaba siempre con el obrero urbano, el campesino, el estibador portuario, el trabajador tradicional y sindicalizado. Su hábitat era "la casita humilde", el "rancho o el ranchito" o a lo sumo el conventillo o la pieza de pensión. Su actitud era humilde y expectante. Su destino podía llegar a ser revolucionario, pero sus hábitos eran moralmente correctos (en contraposición a los de los ricos). Era una pobreza digna, emprendedora, trabajadora, sana. Los niños eran el futuro y las mujeres, "las compañeras". La única mancha que podía sobresalir era el consumo excesivo de alcohol, que se justificaba por las penurias que los pobres debían soportar. El pobre era naturalmente solidario y luchador ${ }^{24}$.

Esta concepción está totalmente ausente en el imaginario de la cumbia villera. En ella, la pobreza no es algo de lo que haya que lamentarse, pero su exaltación ya no es revolucionaria sino profundamente conservadora: los villeros no van a generar ningún cambio social. Las letras reivindican al pibe marginal, más o menos ladrón, adicto al alcohol, pegamento y otras yerbas, que sueña con ganar la lotería o robar para situarse sobre sus compañeros de villa y no quiere - no es que no pueda - trabajar. Clásica visión de la burguesía sobre pobres y explotados y principal razón por la que la cumbia villera cuenta con amplia difusión en radios y TV. Lo único que comparte el estereotipo "pibe chorro" de la cumbia villera con obreros, desocupados y estudiantes en lucha, es su odio hacia la policía, asunto menor que no incomoda a las industrias del disco y a los medios de difusión, aunque sí a los propios policías.

22 COLONNA, Lucas: "El debate por la cumbia en la oficina de Kirchner" en La Nación, Buenos Aires, 5 de agosto de 2004. Alude al programa de "La Tota Santillán". La premura en recibir al presentador y las declaraciones del presidente fueron ampliamente criticadas en los medios de comunicación, como una actitud demagógica, ya que el sector que gusta de la cumbia villera representa muchos votos para el peronismo en el Conurbano y la provincia de Buenos Aires.

23. Martín Fierro era un prófugo de la ley, al igual que sus pares Juan Moreira o el Hormiga Negra; o los gauchos mendocinos Juan Francisco Cubillos y Juan Bautista Bairoletto; del sanjuanino José Dolores Córdoba, del tucumano Marcos Bazán Frías, del correntino Francisco López, del catamarqueño Julián Baquisay y el más celebre de todos, el correntino Antonio Mamerto Gil Núñez, más conocido como el "gauchito Gil. Todos ellos perviven en el imaginario popular. Cada uno tiene su santuario, su estampita o la anécdota que de generación en generación se viene trasmitiendo. El reconocimiento a los gauchos rebeldes devino, en estos casos, en una forma de sacralización popular de la "barbarie" en el sentido del debate suscitado en la obra de Domingo F. Sarmiento.

24 NARODOWSKI, Mariano: "Códigos de la cumbia villera" en Los Andes, Mendoza, Sección Opinión, 2 de febrero de 2004. 
Sus letras expresan códigos y frases de jóvenes marginales, que se juntan en cualquier esquina a tomar cerveza, haciendo chistes desprejuiciados y sin tabúes. Hablan de las drogas, la sexogenitalidad (con la imagen de la mujer al servicio del varón), la policía, la violencia, la discriminación y la falta de oportunidades sociales. En el argumento de sus canciones no hay más proyecto de vida, que la supervivencia en forma marginal y fuera de la ley como salvación individual. Veamos algunas de las principales temáticas que dicho género musical desarrolla.

\section{La reivindicación de los códigos de vida de los excluidos.}

La marginalidad es sin duda el ámbito clave en torno al cual se gesta esta identidad. El que vive en la villa no es considerado "ciudadano", se le niega toda posibilidad en el ámbito educativo y económico porque la villa se coloca en el lugar de la miseria, la droga, la discriminación, la promiscuidad, el sida, los chicos abandonados, los padres borrachos, etcétera. Características propias de una sociedad que vive un proceso máximo de desestructuración social y familiar.

Los mismos grupos musicales describen su situación y su mensaje. En la página de Meta Guach ${ }^{25}$, junto a la denuncia de la corrupción que aboca a la miseria, observamos una conducta resignada que vislumbra el más allá como una proyección de la vida presente, así puede leerse:

"Somos villeros porque Dios así lo quiere y no renegamos de Dios, sino de aquellos que se quedan con el pan, los libros y los medicamentos de nuestros chicos, condenándolos a la desnutrición, la ignorancia, la enfermedad y porque no a la muerte, cuando esto ocurre sólo nos queda el consuelo de saber que Dios se lo llevó a uno de nuestros hijos porque necesitaba un ángel carita sucia.

Queremos dejar en claro que estos 12 temas bajo ningún punto de vista son canciones de protesta, simplemente le pusimos música a nuestras historias de vida, a las cuales un poco de alegría no les haría mal, para que las lágrimas que recorren nuestra mejillas se frenen con la sonrisa de los labios, esos labios que estamos cansados de apretar para no sentir el sabor amargo de las lágrimas”.

La villa es ese "basurero" donde se amontonan los despojos de una nación que se está descomponiendo. El público de estos recitales son chicos de entre 14 y 20 años. Se trata de una generación que no tiene cabida, que no tiene perspectivas. Esa generación que viene tras dos o tres generaciones de desocupados, y aunque pareciera que sobra, decidió arraigarse y forjarse una identidad a partir de aquello que tienen en común, del territorio que comparten, esto es, el sentirse villero. Porque lo que comparten, en definitiva es el dolor. Y ese dolor, lo devuelven distorsionado.

“El corazón yo lo tengo /Pintado celeste y blanco/Porque yo amo a la Argentina y además acá nació el Diego /No me cabe el conchetaje /I am sorry tómatela /Yo nací acá y acá me muero el mismo cielo en que nació el Diego /Siempre seré zarpado de Argentino, fanático del Diego y fan club de nuestro vino (bis) /No me vengan con Jamaica ni con Estados Unidos /Porque yo amo a la Argentina y además acá nació el Diego / Que Microsoft que pininglish /I am sorry tómatela /Yo soy de acá y acá me quedo el mismo cielo en que nació el Diego Siempre seré zarpado de Argentino, fanático del Diego y fan club de nuestro vino (bis) 26" ("Made in Argentina", grupo Los Pibes Chorros).

25 http://metaguacha.tripod.com.ar/ [diciembre, 2005].

26 El Diego, obviamente hace referencia a Maradona; conchetaje = modales y costumbres refinados; zarpado = excederse o propasarse con algo. 
En esta canción hay una exaltación de la identidad nacional, un sentimiento del más puro nacionalismo, expresado a través de la bandera, del idioma (se hace una ridiculización del inglés, de cuyo dominio se jactan las clases medias argentinas, con un uso excesivo de términos y expresiones en inglés dentro del lenguaje cotidiano), religión (la idolatría a Maradona, un autentico símbolo nacional) e himno; todo lo que conforma la identidad argentina.

Te quieren correr / nos quieren barrer / te tiran el rancho / y el tuyo también /Dicen que mi barrio está lleno de hampones / que sólo es un fuerte de droga y ladrones /En sólo una hora se llenó de botones / para tirarlo abajo / y levantar mansiones. / Y ahora tirado estoy / debajo de un puente voy / porque somos marginados /en pelotas nos dejaron / Y ahora tirado estoy / dónde vamos a parar /quemen gomas en la calle / que mi fuerte hay que salvar.( "100\% villero" Grupo Yerba Brava $)^{27}$.

En esta otra canción hay una apelación a la resistencia, a la defensa del barrio frente a la especulación inmobiliaria. A lo largo de la década de los '90 el norte del Conurbano Bonaerense se llenó de countries o barrios cerrados. En este diseño urbanístico, las villas miserias que circundan los barrios privados, aparecen como elementos discordantes del nuevo paisaje urbano diseñado para la clase media alta, de ahí la difícil convivencia y tal vez, los intentos de erradicación de los entornos villeros que describe la letra de esta canción.

En la cumbia villera no hay futuro porque en el conurbano no hay destino. Se vive al día esperando un golpe de suerte: sea un golpe exitoso al banco de la esquina, la loto, la hija afortunada, el camello del barrio. Lo que sea. Es la Argentina que vive al día, que se posterga todos los días, hasta quedar rezagada otra vez. Pero lo que queda afuera no se resigna. No se dispone a tener que aceptar con sufrimiento el lugar que le tocó:

¿Con todo el sentimiento; Cumbia , chapa y meta guacha;

Hace frío en la calle /y se siente muy sólo/con sus años gastados/años de trabajo,/hoy se juega todo/con su angustia en la caral empuñando un papel/ve pasar en la cuadral un auto lujoso, observando que para/sin preguntar quien eral pide su billetera/y con mucha vergüenza le pide perdón/con el arma en la mano/y entre forcejeos/ cerrando los ojos aprieta el gatillo/alertó a una patrulla que estaba de ronda por ese lugar/y queriendo escapar en gran cantidad/perforaron su cuerpo /y llegaron canales de las cuatro puntas de esta ciudad/se dijeron mil cosas/saliendo en la tapa de todos los diarios/ pero nunca se supo lo que halló el forense en la morgue estatal/una simple carta que en su bolsillo guardaba ese hombre/diciendo "papito estamos enfermos y plata no hay”. ("Plata no hay", grupo Meta Guacha) ${ }^{28}$

El sentimiento de marginalidad los hace diferenciarse y adoptar una subcultura muy clara sin intenciones de una movilidad social ascendente. De ahí, que no tengan interés en ningún intercambio social, es una música o ritual subalterno que no niega su subalternidad. Las pautas de distanciamiento social están muy claras: un "villero" o "negro" (persona que vive en la villa) no es, no será, ni quiere ser un "careta" o un "cheto" (persona de clase media para arriba). Esto se observa en muchas letras de sus canciones, como "Negro del Plan" del grupo Meta Guacha :

27 Rancho = casa humilde, vivienda; botones = policías; quemar gomas, es lo que hacen los piqueteros cuando cortan las carreteras; fuerte $=$ aplicado a la villa , como sinónimo de resistencia

28 En la canción "Plata no hay" del Grupo Meta Guacha, el delito aparece como la única salida, como una justificación ante la exclusión social. 
"Tienes la piel mas clara,/paseas en auto por la ciudad/Yo vivo en un barrio pobrel donde se aguanta a mate y pan,/ No se quien te dio derecho/ Para decirme Negro del Plan/Ya sabes que a este negro, /donde tu quieras lo podés probar/Y el que gasta el asfalto/ cuando camina para Lujan/ Que se sangra las rodillas rogando frente a la catedral/ Aquel que llega con hambre,/ porque no tiene para comprar /El que pide por tu mesa /Y que tu llamas negro del Plan/ El que pide por tu mesa/ Y que tu llamas negro del Plan ("Negro del Plan" del grupo Meta Guacha).

Se hace referencia a los Planes Jefes de Hogar, a los 150 pesos del Plan Social, que para muchos es el único ingreso con que cuenta mensualmente. Sólo en las letras de este grupo hemos encontrado referencias religiosas, concretamente a las peregrinaciones a la Virgen de Luján, de gran raigambre en el Conurbano. En la canción, su religiosidad se presenta como una garantía de la rectitud de su conducta; pero en todos los demás grupos no conocemos ninguna otra letra en que se empleen mensajes religiosos.

También en la forma de iniciar las canciones, arengando a su público para identificarlos encontramos otro medio de diferenciación:

¡Toda la vagancia haciendo palmas! (Guachín); ¡Arriba las palmas de todos los negros!(Dama\$ Grati\$); ; Aguanten los pibes chorros! (Pibes Chorros).

El villero aparece descrito como un delincuente, un fuera de la ley. En la villa no se trabaja, se "chorea". La Policía está vista como un antagonista central pero no en los términos represores que denunciaba la canción protesta de los setenta sino en términos delictivos: mientras que el pobre de antaño se percibía como infractor natural de los códigos de una sociedad injusta, el villero de la cumbia villera es un contraventor natural del Código Penal. La cumbia villera nos muestra como natural algo que para la tradición moderna era anatema: el niño ladrón, o lo que es lo mismo, el pibe chorro.

Todos se hacen buena fama /Estudiando y trabajando,/Yo me hice mala fama/ Escabiando y fumando/ Soy mala fama/No tengo solución/No me refugio/Ni corro como vos... ("Soy" del grupo Mala Fama ${ }^{29}$.

"Llegamos los pibes chorros/ queremos las manos de todos arriba/ porque al primero que se haga el ortiva por pancho y careta le vamos a dar.

Aunque no nos quieran somos delincuentes /vamos de caño con antecedentes /robamos blindados, locutorios y mercados /no nos cabe una estamos rejugados/Vendemos sustancia y autos nos choreamos/ hacemos de primeras salideras/ en los bancos somos estafadores/ piratas del asfalto/ todos nos conocen por los reyes del afano" ("Llegamos los pibes chorros" del grupo Pibes Chorros ${ }^{30}$ ).

Ya vimos con anterioridad, al mostrar la letra del primer gran éxito de "Sos un botón" del grupo Flor de Piedra, como la temática de rechazo y odio a la policía es una de las constantes de este género:

29 El término escabiando, quiere decir bebiendo alcohol. En esta letra se muestra con orgullo la elección de vida, frente a las pautas sociales imperantes.

30 Expresiones significativas utilizadas: ortiva = derivado de "cara de orto"(culo, en Argentina cola), persona de carácter amargo o que rechaza una invitación a una acción general; pancho $=\mathrm{el} \mathrm{n}{ }^{\circ} 1$; careta $=$ falso, que actúa de maneras distintas según las circunstancias. Haciendo una orgullosa ostentación de su historial delictivo: chorear = robar; salidera $=$ robo en que se sorprende a la victima saliendo de un banco; piratas del asfalto = modalidad de robo muy extendida en la provincia de Buenos Aires, que consiste en interceptar en la carretera y robar un vehículo que lleva mercancías, que después se venden; afano = robo. 
Todo el día estas patrullando la ciudad/haciendo abuso de tu chapa policial/pero no sabes lo guampudo (cornudo) que sos /por que a tu mujer me la estoy comiendo yo /Policía, Policíal que amargado se te ve /cuando vos estás patrullando /me la como a tu mujer ("Poliguampa" del grupo Pibes Chorros).

En esta otra canción se repite la aversión hacia la policía, degradando sus funciones y mostrando que los verdaderos delincuentes, no son precisamente los villeros:

Siempre querés ser mas/ Bardeás ${ }^{31}$ a los vagos, no te la aguantás!/Crees que tu traje impone respeto /Que podés pegarme, si no me quedo quieto/ Decís que te llame oficial Juan Pérez. Pero vos a mí me llamas delincuente /Que robo, que mato, que soy asesino Yo estaba en la esquina chapándome un vino/ Se me acercó el oficial Juan Pérez, diciéndome... ¿ ¿documento si tienes ?/Y yo le dije, los chorros están enfrente./ Con traje y corbata ...cagando a la gente/ ("Juan Pérez" del grupo Pibes Chorros).

\section{El hedonismo lumpen: la apología de la evasión y la diversión.}

Ante los problemas, el ejemplo que la cumbia villera transmite a sus seguidores, es la evasión, prefieren olvidarse del excluyente mundo en el que viven, emborrachándose, drogándose, yendo a bailar, etc. en lugar de buscar una solución factible, como hace mucha gente que en ese contexto en vez de optar por la delincuencia, cuando no tienen medios, trabajan como cartoneros o cirujas, dedicándose a recolectar todos los días cartones, botellas, latitas o limpiando coches, etc.

Los valores promovidos en las canciones estimulan aún más el crecimiento de esta música, incitando a llevar a cabo su forma de vida, utilizando ciertos códigos como por ejemplo la vestimenta, las palabras alusivas a objetos y comportamientos, etc. Hay ciertas normas que la sociedad en general toma como base, pero en este entorno son transgredidas y estimuladas, por ejemplo robar, drogar, alcoholizarse. Con relación a esto, en los recitales del grupo "Dama\$ Grati\$”, cuando cantan su canción "Quiero vitamina”, se invita al público a cambiar la palabra "vitamina" directamente por "cocaína", sin ningún tipo de prejuicio moral.

La huida de la realidad mediante la exaltación de la sexogenitalidad y la ebriedad de los sentidos, convierten las letras de las canciones en una apología de la sexogenitalidad anal y oral, además de un constante panegírico del vino o la "birra" (cerveza), pero especialmente del pegamento ("poxirán", cuyo uso afecta especialmente a los más jóvenes), la marihuana y la cocaína. Una exaltación del apego a estas sustancias aparece con algún matiz en alguna canción sobre los males que la cocaína puede acarrear o sobre la imposibilidad (o incluso la inutilidad) de "rescatarse". "Aguantar" y "tomar falopa" son las voces de mando de la cumbia villera. Pero la ingesta no tiene un fin experimental o de compensación frente a problemas sociales sino que forma parte de la constitución de la propia identidad villera:

"Mi abuela me decía no debes mentir /porque sino te va a crecer la nariz / yo no le hice caso /y ahora tengo este naso/ también me decía no debes fumar /no andes en la joda y deja de tomar/y gritaba como loca /deja el vino y toma coca /deja el vino y toma coca //y ahora yo con este naso /tomo coca y no del vaso /coca y nada mas /coca y nada más "( "Mi naso" del grupo Yerba Brava). ${ }^{32}$

31 Bardeás = provocar problemas.

32 Naso: nariz, tomar: beber, Joda: juerga 
“;Con sentimiento , cumbia, chapa y meta guacha; Una noche de locura aspiré todo tu cuerpo/y enloquecíl te metiste en mi cabeza/ me llevaste hasta las nubes / Y de tu mano/ a volar aprendíl Y cuando llega el bajón lentre música y alcohol/ necesito más de ti/ cada vez me haces más falta/ sopla Dios al que me mata / pero yo te quiero en míl blanca y radiantel dicen que me haces mal, que me vas a matar. ("Blanca y Radiante 33 “ del grupo Meta Guacha).

También el consumo alcohólico se pondera:

"Y nosotros puro ritmo,/ vino tinto y sustancia." ("La marca de la gorra" de Mala Fama). "Yo quiero tomar vitamina/ me compro una bolsa/ y estoy pila - pila/ no puedo caminar de tanto jalar" ("Quiero vitamina" de Dama\$ Grati\$). "Yo tengo una flor,/ la tengo que cuidar,/ cuando sea grande I me la voy a fumar/ aunque sea ilegal /para mí es medicinal.” ("Mi flor” - Dama\$ Grati\$).

No es una música apolítica, sino que está en contra de la política. Para sus seguidores el poder no está en las instituciones republicanas, la opresión capitalista o el imperialismo: el poder es el dinero, las drogas o el sexo. No hay proyecto político que defender más que la propia subsistencia. No hay revolución, sólo "aguante", entendido como complicidad frente a la Policía, a las adicciones, a la ilegalidad en genera ${ }^{34}$. Reproducimos la letra de la canción "Pibe Cantina" del grupo Yerba Brava que al parecer está inspirada en la figura de Pablo Lescano, el creador del género cumbiero, vocalista de Dama $\$$ Grati $\$$ y productor de varios grupos, que continua viviendo en la villa La Esperanza en San Fernando (Buenos Aires.), aunque él no sólo no le ofende, sino que, por el contrario, le gusta que le llamen así según declaró en una entrevista. ${ }^{35}$

En los pasillos de la villa se comenta, /que el pibe cantina, /se ganó la lotería. /Ya no pasea con su bici despintada, /no usa su gorra, /zapatillas desatadas... / Y se viste elegante, /todos lo ven. /Luciendo su rolex, /ese pibe anda bien... /Pibe cantina de que te la das, /si sos un laucha, borracho y haragán. /Las chicas del barrio te gritan al pasar, /"dale guachín, sácanos a pasear". / Pibe cantina que andás con la coupe,/ lentes oscuros, hay como te ves. /Anillos de oro, cadenas también,/ya no sos el mismo, déjate de joder ${ }^{36}$.

Aún después de haber triunfado con su música Pablo Lescano ha sido detenido en dos ocasiones por portar armas y allegados al grupo se han visto implicados en secuestros y atracos ${ }^{37}$. La cumbia villera no propone ni el bien común ni el del sector al que pertenece, sino la salvación individual, usualmente por la vía del delito contra la propiedad (en general contra la pequeña propiedad, pobres contra pobres) y la autodestrucción. Por eso las referencias a la cárcel, a los amigos que quedaron en el camino son frecuentes, recopilamos aquí algunos fragmentos:

33 La canción narra la experiencia primera de iniciación al consumo de la cocaína, que se describe, metafóricamente, con una pasión amorosa, tanto por el título de la canción (blanca y radiante como las novias), como por la necesidad constante de la persona amada.

34 Ibídem: NARODOWSKI, Mariano: "Códigos de la cumbia villera" en Los Andes, Mendoza, Sección Opinión , 2 de febrero de 2004

35 RIERA, Daniel: "El ritmo de la villa" en Revista Rolling Stone, Buenos Aires, julio de 2001. pág. 12. Cuando el reportero acudió a su casa, en la entrada dos Mitsubishi aparcados en el porche de la casa, un GT3 rojo, un Eclipse amarillo y un Ford Escort blanco con una tigresa pintada en el capó, eran de Pablo Lescano.

36 guachín : en sentido cariñoso es una persona joven, un chico; coupe $=$ alude al modelo de coche.

37 En esta página, una de las principales de la movida tropical y la cumbia villera, se da cuenta puntual de las detenciones sufridas por Pablo Lescano. http://www.fantasticobailable.com/g_damas.htm [diciembre, 2005] 
"Dos años guardado estuvo,/ por fin la yuta hoy lo largó" ("La canción del yuta” del grupo Yerba Brava). "Ahora nosotros tomamos el control/ somos los dueños del pabellón/ estamos cansados de tanta represión/ y vamos a tomar esta prisión” ("Los dueños del pabellón” de Dama\$ Grati\$). “ Hace tiempo que anda ganando/ y la yuta no lo puede atrapar"( "El alto chorro" de Amar y yo) ${ }^{38}$.

"Estoy de nuevo en la calle /me dieron la libertad/Hace un año y siete meses /que extrañaba la ciudad/y estoy, estoy de nuevo/ como quiero estar/ sábado alta joda/ cantando sin parar/ritmo sustancia/ cumbia y nada más." ("Estoy de nuevo” de Mala Fama).

\section{E. La mujer como objeto sexual para la cumbia villera.}

Las mujeres son permanentemente denigradas en las letras de la cumbia villera. Uno de los ejemplos más concretos pueden ser el de "Dama\$ Grati\$” que en su mismo nombre ya hace referencia a la prostitución. En la cumbia villera, las mujeres nunca son "compañeras". O son "las pibas", y en ese caso son cómplices asexuadas, o son objetos sexuales evidentes. Son explícitamente "putas", pero no en sentido tradicional de una prostituta sino en el de mujeres fáciles, a las que se les asigna una actividad sexual despreocupada y al servicio de la coacción masculina. Casi no hay canciones de amor (excepto de amor a la cocaína) y las mujeres no son idolatradas como en el bolero, el cuarteto cordobés o la cumbia tradicional ${ }^{39}$. La cumbia villera, en cambio, describe a las mujeres jóvenes como prostitutas y/o ninfómanas. Tal vez subyace en ello un resentimiento masculino tras la caída del papel del hombre-proveedor-cabeza de familia, ante el gran aumento de las jefas de hogar en el contexto de la crisis. La letra de "La cumbia de las chapas" del grupo Meta Guacha muestra la indolente pasividad del villero que se recrea en la fiesta, mientras espera que la mujer traiga el dinero a la casa, generalmente trabajando como mucama (asistenta):

Suena la cumbia / y los tambores /todo el villerío está de fiesta, /traigan el vino /mucha cerveza /que el día es nuestro y hoy se festeja, /como no hay monedas /ni una "changuita ${ }^{40 " ~ e n c i m a ~}$ llueve, me quedo en casa, /pone una cumbia /colombianita /que la acompaña el ruido de las chapas. ISi vine la negra estamos completos /cerveza, vinito, mortadela y queso/Si vine la negra estamos completos /ruidito a chapas, cigarrillo y sexo.

En las letras hay una carencia de historias y situaciones vividas por las mujeres, únicamente cuentan experiencias del sexo masculino, las calamidades sociales y el hacinamiento, llevan a una convivencia muy cercana y una mayor promiscuidad, que conduce a la exaltación abierta, en las letras de las canciones, de la sexogenitalidad oral y anal, como paradigmas del goce masculino.

Son numerosos los ejemplos que podemos mencionar en los que se muestra la visión degradante que, sobre el sexo femenino, existe en una buena parte de sus temas:

"Laura.../Tú bailas de minifalda/que risas que me da/ porque se te ve la tanga/ y no podés esperar/ que te lleven de la mano/ y te inviten a un hotel./No lo haces por dinero,/ solo lo haces por placer. ("Se te ve la tanga" del grupo Dama\$ Grati\$).

\footnotetext{
38 Yuta = policía; ganar $=$ sinónimo de robar. La definición de alto chorro se refiere a ladrón de bancos .

39 Común a casi toda la música latinoamericana es esa veneración y rendición incondicional hacia el sexo femenino, un reverso de la situación real de las mujeres en el continente.

40 Changuita o changas son trabajos esporádicos.
} 
"Si pinta una cumbia, revoleas tus caderas/Si pintan los tragos, vos perdés el control/ Y si pinta la guita, nunca decís que no/, Ay, Andrea, vos sí que sos ligeral Ay, Andrea, te gusta la fijal Ay, Andrea, qué astuta que sos" ("Andrea” de Los Pibes Chorros).

Basta con cambiar alguna que otra consonante para captar su verdadera intención, algo que se pone de manifiesto cuando el público corea estribillos como el citado, en las bailantas. La pornografía se acepta como "fuerza liberadora" antes que como un modo de explotación. Únicamente las mujeres aparecen en las letras de la cumbia villera como objetos sexuales al servicio del hombre, el descrédito que la cumbia villera le hace al sexo femenino, es tan evidente que resulta difícil entender que muchas adolescentes sigan fanáticamente a estos grupos, como por ejemplo en la página del grupo "pibes chorros"41 podemos observar como un grupo de fans integrado únicamente por chicas, se autodenomina "Las lecheras" a raíz de una canción del grupo que habla de que una tiene "aliento a leche".

Déjate de joder y no te hagas la loca,/ anda a enjuagarte bien la boca /me diste un beso y casi me matas/ de la baranda a leche que largas./ No te hagas, la nena de mamá /porque ese olor a leche que sale de tu bocal la vaca no lo da./ Me enteré lo astuta que sos, / que te gusta la fija /y que sos mas fácil que la tabla del dos./ ("La Lechera” del grupo Pibes Chorros).

Incluso hay un grupo cumbiero encabezado por una chica, llamado "La piba", que hace referencia a que va "a la cancha con pollera y sin bombacha ${ }^{42}$ ". Estaría de más desarrollar el tema de sus canciones, ya que son iguales o peores que las interpretadas por hombres.

La visión tradicional de clase media que convertía a cualquier villero en un marginal de la ley y a cualquier villera en prostituta, se ha convertido en la expresión estética de los que dicen pertenecer a la villa y cantar lo que en ella acontece. La cumbia villera nos acostumbra a que no hay otro destino posible para la exclusión social y nos muestra como natural lo que es el efecto de condiciones políticas y económicas. Hay una aceptación pasiva y acrítica de la visión naturalista que se ofrece. Ganar dinero y pasarlo bien son reclamos de la cumbia villera. Pero la picardía de los villeros de la cumbia residió en hacer suya la "lealtad de barrio" lo que les asegura la pléyade de seguidores.

Los conjuntos de cumbia villera se mueven por circuitos estrictamente empresariales, no han asomado por huelgas, ni en los piquetes o cortes de carreteras; la preocupación social no es una de sus prioridades. La cumbia villera es una variante naturalista del mundo de las villas, una rebeldía de esos sectores, pero en ningún momento se plantean una rebelión contra la situación que los excluye y expulsa del sistema. De ahí que los medios seguirán sosteniendo y también, criticando a la cumbia villera porque la burguesía necesita, en la etapa actual, la imagen del villero ante la sociedad como "pibe chorro", aunque sean estos una minoría dentro de la población de las villas, pero si cae la imagen del "pibe chorro" aparece inevitablemente la del piquetero (y en menor medida la del cartonero, que tampoco conviene a la burguesía). La cumbia villera es una creación subalterna que acepta su subalternidad y el "orden" impuesto por el sistema social injusto.

La carencia material, cuando llega a la indigencia y la hambruna, trae consigo la miseria moral, que, si bien no es privativa de la pobreza, encuentra allí un caldo de cultivo. La exclusión significa falta de contención. La escuela deja de ser mala para ya directamente no ser; la vivienda es un inmundo redil de hacinamiento y promiscuidad; la Justicia como el Estado, grandes ausentes; las fuerzas del orden, un cuerpo que fluctúa entre la represión violenta y la corrupción pseudo

41 http://www.siemprechorros.com.ar [diciembre,2005].

42 Se denomina así a la prenda interior femenina. 
protectora, y los políticos, "charlatanes" que, en el mejor de los casos, actúan como repartidores de "limosnas y caridades" por medio de sus punteros políticos, especialmente cuando se acercan las citas electorales. Este intrincado juego de desgracias crea un ambiente social de bronca y resentimiento, de furia y escepticismo.

Es en medio de este caos, donde algunos jóvenes se ponen a cantar lo que vivieron desde la cuna, o lo que conocieron de cerca aunque no les haya tocado pasarlo personalmente. Lo vuelcan en versos y le ponen música. Ellos no construyeron esta desgracia, simplemente la cantan, a pesar de que se les quiere responsabilizar de la falta de respeto a la autoridad e incitación a la violencia.

Quizás en unos años más desaparezca o queden apenas recuerdos de esta aventura sonora, pero aunque esta cumbia villera no sea cumbia, ni pueda definirse sólo villera, sus señales quedarán grabadas en el inconsciente colectivo como un sesgo crudo y brutal sobre la marginalidad y la exclusión que la crisis puso de manifiesto.

\section{EL TEATRO BARRIAL O COMUNITARIO}

Una de las actividades culturales de mayor prestigio en el panorama cultural argentino la constituye el teatro, que siempre fue considerado como uno de los mejores de América Latina. Buenos Aires, aún en tiempos de crisis, sigue ofreciendo una abundante cartelera teatral en los espacios convencionales e independientes, pero el teatro también circula por otros ámbitos: los festivales, el ciclo Teatro por la Identidad, la movida teatral que sale a la calle, a las plazas, o lleva a cabo sus funciones en casas particulares, en las trastiendas de las librerías de la calle Corrientes y hasta en el metro. El Teatro Colón ${ }^{43}$, el San Martín y el Cervantes con sus actividades gratuitas atraen públicos ávidos ${ }^{44}$. Todo ello sin contar la programación de ARTEI (Asociación Argentina del Teatro Independiente), integrada por 33 salas teatrales asociadas, en donde se representaban 95 obras diferentes ${ }^{45}$.

Sólo un dato que pone de manifiesto el interés y la importancia que la representación teatral reviste en el país ${ }^{46}$ : al crearse el Instituto Nacional del Teatro (INT), que comenzó su andadura en febrero de 1998, con la finalidad de apoyar al teatro no estatal ni comercial, se elaboró un registro que sacó a la luz la existencia de unos 1.500 grupos estables y 500 salas en todo el país ${ }^{47}$.

43 El Teatro Colón se encuentra entre las mejores salas líricas del mundo, con una espléndida arquitectura y una acústica perfecta (se dice que la segunda del mundo, tras la Scala de Milán); es el lugar de cita de las más prominentes figuras del mundo de la música clásica, el ballet y la ópera. Terminado en 1907, tiene capacidad para 2490 espectadores. Otros teatros de envergadura son el Nacional Cervantes y el Municipal Gral. San Martín. PAGELLA, María Gabriela: Argentina .Ed. Anaya, Madrid, $2^{\circ}$ Ed, 2002, pág.43.

44 Tanto el San Martín, en el área municipal (y el conjunto que de él depende, denominado Complejo Teatral de Buenos Aires), como el Cervantes, en el área nacional, destinan salas (la Cunill Cabanellas en uno, la Orestes Caviglia en el otro) a obras de autores noveles y a experiencias originales.

45 La relación de teatros adscritos y las diferentes representaciones pueden consultarse en la página web: http://www.arteiteatros.com.ar/index 1.html/

46 Existen tres instituciones oficiales que otorgan subsidios y préstamos para facilitar y fomentar la actividad teatral, con especial interés en los grupos jóvenes y en los que actúan en el interior: el Fondo Nacional de las Artes y, específicamente, el Instituto Nacional del Teatro, y Proteatro (para la Capital). Cada dos años, el Festival Internacional de Teatro, Música y Danza de Buenos Aires, produce un bienvenido intercambio con manifestaciones de otros países. Limitado en las dos últimas ediciones por la notoria crisis económica, pero de todas maneras fructífero y fervorosamente seguido por un público entusiasta. SCHOO, Ernesto: "Teatro en Buenos Aires, hoy" en La Nación, Buenos Aires, Sección Cultura, 24 de abril de 2005.

47 Creado a partir de la Ley Nacional de Teatro sancionada en 1997 (por la que la profesión luchó durante medio siglo). El presupuesto recibido por cada provincia fue siempre inferior al asignado, ya que al depender de Hacienda, los recursos asignados al INT son de los primeros en sufrir los ajustes del presupuesto nacional., no obstante, su acción es importante especialmente, en las zonas más incomunicadas del interior del país. VASSALLO, Marta: "El teatro una pasión argentina. Resistir en las grietas" en Le monde diplomatique, Edición Cono Sur, Buenos Aires, nº 18, diciembre de 2000, pág.31. 
Cambia la dramaturgia, vacilan los cánones tradicionales de la crítica y, sobre todo, el público responde. Un público interesado, curioso y entusiasta. Y no sólo compuesto exclusivamente por jóvenes, sino por público de todas las edades, hasta los más pequeños (asombran la calidad y variedad del teatro para niños) participan de este fenómeno apasionante que es el auge del teatro en Buenos Aires. Sin ese público, sin su exigencia y su fervor, esta eclosión no habría sucedido.

La originalidad y la variedad de las propuestas indican que la tendencia está muy lejos de agotarse. Hay semanas de hasta cinco o seis estrenos, y aperturas de nuevas salas. Otro rasgo curioso, no compartido con ninguna otra cartelera en el mundo, es la abundancia de funciones de trasnoche, que convocan a los más jóvenes, para quienes la vida comienza a la madrugada. Y aquí se observa una modificación importante en la forma del teatro independiente. Lo habitual era que el grupo alquilase un sótano o un local en desuso en la zona céntrica o lo más cerca posible a ésta. Hoy, se prefiere la compra de un caserón ruinoso en un barrio alejado (favoritos: Villa Crespo, Almagro, Abasto, los distintos Palermos) para restaurarlo, adaptándolo a tres fines: vivienda del maestro o director, escuela y área de actuación. Los ejemplos: El Doble, de Lorenzo Quinteros; El Sportivo Teatral, de Ricardo Bartís; El Excéntrico de la 18, de Cristina Banegas; Taller La Maravillosa, de Inés Saavedra; Teatro del Sur, de Alberto Félix; Patio de Actores, de Laura Yusem.., es decir, los nombres más destacados de la renovación teatral en la ciudad. A éstos deben sumarse (a riesgo de olvidar alguno) los responsables de otras salas destacadas, como El Ombligo de la Luna, El Camarín de las Musas, El Kafka, Del Artefacto, El Portón de Sánchez, Anfitrión...,casi tantas estéticas diversas como salas ${ }^{48}$.

Nuestra época se encuentra atravesada por la experiencia de la globalización, la fractura de los discursos totalizadores y el multiculturalismo. La sociedad de consumo y los medios tecnológicos condicionan fuertemente la vida cotidiana y las relaciones sociales, situación que entraña también una crisis de los marcos teóricos establecidos y, por lo mismo, un cuestionamiento de los cánones y valores tradicionales. El teatro no ofrece ya un ámbito para la unidad sino que ostenta materiales heterogéneos y, al mismo tiempo, el concepto de teatralidad escapa a las limitaciones de una categoría rígida y se ofrece como posibilidad múltiple, abierta, redefinida en cada evento teatral. De manera que para Jorge Dubatti, uno de los mejores conocedores del teatro argentino de la postdictadura:

"El canon del nuevo teatro argentino, se caracteriza por la atomización, la diversidad y la coexistencia pacífica, no beligerante, de micropoéticas y microconcepciones estéticas, por lo que elegimos llamarlo el "canon de la multiplicidad". Las nuevas condiciones estéticas generan un paisaje teatral "desdelimitado", de "proliferación de mundos" diversos. El efecto de la diversidad recorre todos los órdenes de la práctica teatral actual. Se observa tanto en el estallido de las poéticas dramáticas y de puesta en escena, como en las ideologías estéticas (implícitas en las obras o explicitadas teóricamente), las formas de producción y los tipos de público, así como en la aparición de nuevas conceptualizaciones para pensar el fenómeno de la diversidad ${ }^{49}$ ".

(...) "Se ha impuesto un teatro de "teatristas", palabra que encarna constitutivamente la idea de diversidad: define al creador, que no se limita al rol teatral restrictivo (dramaturgia o dirección o actuación o escenografía, etc.), y suma en su actividad, el manejo de todos o casi todos, los oficios del arte del espectáculo" 50 .

Y con este término, teatristas, es como se hace referencia continuamente a los creadores del teatro callejero y barrial.

48 SCHOO, Ernesto: "Teatro en Buenos Aires, hoy" en La Nación, Buenos Aires, Sección Cultura, 23 de abril de 2005.

49 Dubatti, Jorge: El teatro laberinto. Ensayos sobre teatro argentino. Ed. Atuel, Buenos Aires, 1999, p. 19.

50 DUBATTI, Jorge (coord.): El teatro de grupos, compañías y otras formaciones (1983-2002). Micropoéticas II. Ed. Centro Cultural de la Cooperación, Buenos Aires, 2003, pág.412. 


\section{a. Del teatro callejero al teatro comunitario o barrial}

En Argentina se dieron dos extraordinarios acontecimientos políticos-culturales, que seguramente forman ya parte de la historia del Teatro Latinoamericano: el Teatro Abierto y el Teatro por la Identidad.

Ambos surgieron en distintos momentos como necesidad para expresar, en el escenario, circunstancias y vivencias de una época trágica del país. En ambos, asistimos a una repuesta del teatro y su público al oprobio y la injusticia que sufría la cultura.

El mismo espíritu fue el que animó a las agrupaciones que invadieron Buenos Aires -como contrapartida a los años de dictadura y la falta de libertad de expresión- en la última época dorada del teatro callejero: los años 80, en los que la primavera democrática sacó a la gente de las casas. Músicos, mimos, teatristas y titiriteros poblaron calles, parques y plazas, y convirtieron la ciudad en una fiesta.

El movimiento teatral emergente de mediados de la década de los 80, llamado por Osvaldo Pellettieri teatro de parodia y cuestionamiento $^{51}$, fue un movimiento heterogéneo compuesto por actores, directores y dramaturgos, con ideologías y poéticas diversas que cuestionaban las convenciones estéticas del teatro tradicional. Los exponentes de estas tendencias permanecían al margen de los espacios del teatro oficial y comercial, y montaban sus espectáculos al aire libre o en salas no convencionales. Proponían la concepción del hecho teatral como acontecimiento vital, intransferible e irrepetible, la revalorización del cuerpo del actor, la actuación no supeditada al texto y el cuestionamiento de las convenciones establecidas. Expresaban la voluntad de diferenciarse del teatro oficial y convencional, no sólo por la concepción ideológica y estética, sino también en lo que respecta a la modalidad de producción y de circulación.

Hablar de teatro callejero parece hacer referencia en una primera impresión, a esa pléyade de jóvenes que pueblan con sus vestuarios y maquillajes los parques de fines de semana. Sin embargo, el apelativo excede, y en mucho, el simple hecho de plantarse en un espacio abierto y hacer lo propio, gorra mediante. Cuando hablamos de teatro callejero, nos estamos refiriendo a toda una estética y a una compleja mecánica de funcionamiento que hoy sólo unos pocos grupos se esfuerzan por sostener.

En esos años, catorce grupos callejeros, de los tantos que existían, formaron el Movimiento de Teatro Popular (MoTePo), en el que se inscribían Diablomundo ${ }^{52}$ dirigido por Carlos Uriona, Los Calandracas ${ }^{53}$-que aún dirige Ricardo Talento-, La Runfla ${ }^{54}$ comandada por Alvarellos, y Catalinas Sur, por Adhemar Bianchi.

51 PELLETTIERI, Osvaldo: “AA qué llamamos teatro emergente de los ochenta y los noventa?”, en PELLETTIERI O. (dir.). Historia del teatro argentino en Buenos Aires. El teatro actual (1976-1998). Vol. V, Ed. Galerna, Buenos Aires, 2001, pág. 20.

52 Diablomundo es uno de los grupos históricos del movimiento del teatro callejero, que aún subsiste; su director es desde su fundación, Carlos Uriona. El grupo comenzó a trabajar en 1985 y, desde entonces, sus obras han evolucionado con la mezcla de disciplinas y elementos: malabares, títeres, objetos, acrobacia y murga. Al día de hoy, han recorrido "el ochenta por ciento de los barrios de Capital y Gran Buenos Aires", según sus propias palabras, y se han paseado por buena parte del planeta presentando sus espectáculos en festivales de teatro. "Platea a cielo abierto. Cuando el teatro callejero es un género con mayúsculas" en La Nación, Buenos Aires, Sección Vía Libre, 28 de mayo de 1998.

53 Del grupo los Calandracas y de Catalinas Sur, al tener un papel protagónico en el desarrollo de esta modalidad teatral barrial, trataremos con posterioridad.

54 La Runfla, que tomó su nombre de un vocablo lunfardo que significa:"gente de una misma especie unida por un objetivo común", se formó en 1991,bajo el liderazgo de Héctor Alvarellos, con el propósito de investigar, producir y promover el teatro callejero. Desde 1994 desarrolla sus actividades en el Parque Avellaneda. Sigue manteniendo sus espectáculos al aire libre y su creación más importante ha sido "Fuenteovejúnica", una adaptación del clásico de Lope de Vega. "Abordar las calles es siempre un desafío, y hacerlo con un clásico lo es aún más. En este medio es relativamente fácil presentar espectáculos sencillos, y nosotros decidimos apostar a una propuesta de calidad y grandes dimensiones, donde utilizamos dramáticamente los elementos de las disciplinas callejeras, como los zancos, el fuego y los malabares", dice Alvarellos sobre su propia obra. "Platea a cielo abierto. Cuando el teatro callejero es un género con mayúsculas” en La Nación, Buenos Aires, Sección Vía Libre, 28 de mayo de 1998. 
El MoTePo llevó adelante una serie de espectáculos en los que participaban creativamente todas las formaciones, y marcó el punto más alto en la historia reciente del teatro callejero.

Pasó el tiempo y la primavera democrática de los años 80 se convirtió en otoño con la llegada de los 90 - de la mano de la globalización y la economía de mercado-, y el teatro en las calles comenzó a retroceder. Diablomundo, Los Calandracas y Catalinas Sur, dieron un paso adelante y, desde la pureza del teatro callejero, se animaron a pasar a las salas desarrollando espectáculos que presentan una cuidada propuesta estética manteniendo su sesgo inicial. Sólo $L a$ Runfla sostiene aún el concepto de teatro callejero, popular, más allá de las modas de turno.

Estos artistas sostienen que el género posee sus propias técnicas y formas, y rechazan a quienes lo tildan de "género menor". Generar un espectáculo en un espacio no convencional de teatro, implica en primer lugar, aprender a manejar a un público que debe ser seducido y atrapado. En segundo lugar, todos los elementos que hacen a la puesta en escena, cobran una dimensión específica cuando deben desarrollarse en la calle; el vestuario, la escenografía, la música y hasta la preparación de los actores -que contempla una intensa preparación física y vocal-, cambian en su esencia.

Así se fue configurando una variante del teatro callejero, que hoy conocemos como teatro barrial o comunitario. A estos grupos los une la calle, pero también los contenidos, siempre de corte social y con la impronta de las tradiciones del teatro popular rioplatense. Los une también el esfuerzo sostenido, y la autogestión.

En la actualidad, pocos son los sobrevivientes de la época dorada que continúan batallando, no olvidemos que el recambio generacional aparecía en el horizonte como un inconveniente a salvar para preservar la continuidad de la tradición. No obstante, los grupos de Ricardo Talento y Adhemar Bianchi que, al cimentarse sobre el componente barrial (uno en el barrio de la Boca y otro en Barracas), siguieron recibiendo la savia nueva de otras generaciones, manteniendo su actividad y convirtiéndose a partir de 1999 y, sobre todo, de la crisis de 2001, en los difusores de las técnicas y la idiosincrasia del teatro comunitario entre otros colectivos barriales. Bajo las enseñanzas y tutelas iniciales de estos dos "teatristas" han ido surgiendo nuevos grupos, en otros barrios de la Capital, en el Conurbano, e incluso, en provincias tan distantes como Misiones, debido a que, a medida que la crisis fue profundizándose, el teatro como parte integrante de la cultura, se vio "afectado" en su conjunto por este tremendo quiebre nacional.

Y como dice el Grupo de Teatro Barracas, en su obra Zurcido a mano:

\footnotetext{
"Porque nos duele, quisimos contarlo, esto nos pasó., y nos está pasando. Quizás nuestra historia sea parecida a la de otros barrios ${ }^{55}$ ",
}

Tanto Ricardo Talento ${ }^{56}$ como Adhemar Bianchi, son los artífices de La Red de Teatro Comunitario que comenzó a expandirse a partir de los acontecimientos ocurridos en diciembre del 2001.

55 Programa de mano de la obra "Zurcido a mano" del Teatro Barracas y los Calandraca representada en el Circuito Cultural Barracas, avenida Iriarte, 2165, Barracas, el 3 de julio de 2004

56 Ricardo Talento nace en Capital Federal en 1948. Su vinculación al teatro independiente se inicia en el "Teatro de Abril" de la ciudad de Junín, donde pasa parte de su infancia. En 1972, egresa de la escuela de actuación de Hedy Crilla y forma parte de los elencos del Teatro Municipal General San Martín y del Teatro de la Universidad de Buenos Aires.

Asimismo, como actor, pasó por la Comedia de la Provincia de Bs .As. y de la ciudad de Avellaneda. Estudia dirección con los profesores Carlos Alvarenga y Juan Carlos Gené, y dramaturgia con Mauricio Kartun. Ha sido miembro fundador de la agrupación Los Calandracas y desde entonces , ha desarrollado una vasta actividad en la dirección. Junto a los grupos Catalinas, Diablomundo y la Runfla ha montado los espectáculos: "Le robaron el río a Buenos Aires" y "Utópicos y malentretenidos" (1995-6) y con Adhemar Bianchi, ha codirigido al Grupo Catalina Sur en "El fulgor argentino".

Dirigió "Los chicos del cordel" que ha recibido el Premio Metropolitano de Teatro 2000, y fue nominado ese mismo 
Ese momento coincidió con una toma de conciencia por parte de la clase media que se expresó en la movilización, en los cacerolazos, en las asambleas populares, en el trueque, etc... Todo el mundo empezó a necesitar salir hacia fuera y encontrarse. Cuando se rompió la ilusión del primer mundo, mucha gente comenzó a tener la necesidad de reubicarse y de compartir. Y ahí estaba la experiencia de estos grupos que, como un imán, atrajeron a muchas personas porque contagiaban la alegría y la camaradería en un momento especialmente trágico de fractura social. Y fue un momento muy fértil para entusiasmar a vecinos de distintos lugares para que empezaran a organizarse, reunirse y comunicarse con otros vecinos a través del teatro.

Cristina Paravano, nos relata el profundo impacto de 2001 sobre la forma de actuar de la gente en los 90:

"La crisis del 2001 fue un corte también, o sea Argentina estaba sumida en el famoso primer mundo, con toda una idea completamente equivocada y la gente estaba muy entretenida comprando videocaseteras en los supermercados con la tarjeta de crédito, o viajando por el exterior.., y el 2001 nos demostró que eso no era así.., que eso era una especie de invento y la gente se volvió a sentir sola; y bueno, se armaron asambleas populares en los barrios, la gente se quería juntar. Muchas asambleas murieron., pero la gente que se quería juntar lo hace a través del teatro, y es así que las propuestas de Catalinas y los Calandracas, que iban a los barrios, y llevaban "Venimos de muy lejos", atrajo a muchísima gente ${ }^{57}$.

La crisis que vive el país ha tenido una respuesta positiva a través de la aparición de muchos elencos, y resulta sorprendente la fuerza, el entusiasmo y el compromiso ético con que han surgido tantos grupos en momentos tan desfavorables económicamente.

Sostenemos la idea de que la aparición de tantos colectivos de teatro responde a un intento de recuperar la identidad cultural del país empezando por el barrio y el entorno, pero también se erige como un acto de resistencia cultural frente a un mundo globalizado, que tiende a borrar las diferencias culturales.

Recogemos opiniones tomadas al azar, entre el público asistente a la representación de Zurcido a Mano del Grupo Teatral Barracas, una informante anónima nos decía ${ }^{58}$ :

"Me gustó, me gustó mucho; me parece que el grupo de teatro está mucho más fortalecido.., la verdad me ha gustado mucho el nivel, me ha gustado todo: los textos, las canciones, me ha gustado todo.

El año pasado vi el Casamiento de Anita y Mirco, era otro estilo, otra puesta aunque me había gustado, pero esta me colmó realmente, totalmente. Es bárbaro, la verdad que es bárbaro que la gente encuentre un espacio para ser feliz”.

año al premio Trinidad Guevara, a la mejor dirección. En diciembre de 2001, obtuvo el Premio Teatro del Mundo al mejor director. BIDEGAIN, Marcela: "Los Calandracas, una vocación comunitaria" en DUBATTI, Jorge (coord.) : El teatro de grupos, compañías y otras formaciones (1983-2002). Micropoéticas II. Ed. Centro Cultural de la Cooperación, Buenos Aires, 2003,.pág.299-300

57 Cristina Paravano, nacida en Buenos Aires (Capital Federal) el 18 de octubre de 1947, domiciliada en el Barrio de la Boca; despachante de aduanas (empresa familiar) y socióloga, es miembro del Grupo Catalinas Sur desde sus orígenes, llevando a cabo las tareas de divulgación a través de internet, además de numerosas actividades. Entrevista realizada por mí, el 16 de agosto de 2004 en los camerinos del Galpón de Catalinas, en Buenos Aires.

58 Informante anónima $\mathrm{n}^{\circ} 1$ del público asistente al Teatro del Círculo Cultural Barracas. Entrevista realizada por mí, el 3 de julio de 2004, Buenos Aires. 
Otra informante anónima ${ }^{59}$ del público nos comenta:

"A mí me emocionó mucho porque mi abuelo era lechero de esta zona; era un gallego de la zona del Cabo de Finisterre, y me acordé de mi abuelo que le ponía agua a la leche en las casas de la gente que tenía plata, pero no en las casas donde había muchos chiquitos, ahí les daba la leche pura, él era de los boinas blancas; entonces me acordé mucho y me dio mucha emoción. Me gustó. Sí, totalmente, porque todos mis abuelos eran españoles..,así que fue para mi muy lindo, me encantó"

Para otro entrevistado ${ }^{60}$ del público:

"Yo estoy aprendiendo a conocer el barrio de mi mujer a través de estas cosas. Es maravilloso, porque uno revaloriza todo y aparte se encarna con eso, con los personajes.., son cosas lindas ¿no?.., nos pasa a todos, nos pasa a todos”

Otra espectadora ${ }^{61}$ cuando le preguntamos si le gustó la obra, respondió:

"Sí, sí, aparte yo soy de acá y vivo en frente de una autopista; yo sé lo que es, yo sé como se vive. Es difícil. Yo nací en un barrio parecido a éste, no igual pero parecido, donde la autopista destruyó no solamente las casas, destruyó lo que era el barrio, sin lugar a dudas.

Es fantástico, me acuerdo que ahora se da un poco, lo que había antes cuando yo era chica, yo soy del 44, qué en cada barrio había un corso (desfile de carnaval) o varios en pocas cuadras, y siempre había un club, que aunque muy chiquitito a veces, capaz que era una sala nada más, pero ya era el club. Sí, no importa si era grande o no, en realidad era un lugar de expresión y donde poder juntarse, algo que ahora gracias a Dios se está recuperando; porque hubo muchos años en que no se pudo hacer nada”.

\section{Según Humberto Eco:}

“el arte, más que un conocer del mundo, produce complementos del mundo, formas autónomas que se añaden a las existentes, exhibiendo leyes propias y vida personal. No obstante, toda forma artística puede muy bien verse, si no como sustituto del conocimiento científico, como metáfora epistemológica; es decir, en cada siglo, el modo de estructurar las formas del arte refleja el modo como la ciencia, o sin más, la cultura de la época, ven la realidad” ${ }_{2}$

Muchas de las obras y espectáculos del nuevo teatro argentino, constituyen metáforas epistemológicas de la manera actual de ser y sentir del pueblo argentino. Y tal vez, como ninguna otra modalidad, sea el teatro barrial o comunitario la catarsis de esta sociedad en crisis.

59 Informante anónima $\mathrm{n}^{\circ} 2$ del público asistente al Teatro del Circulo Cultural Barracas. Entrevista realizada por mí, el 3 de julio de 2004, Buenos Aires. En la obra uno de los personajes es un lechero gallego, que en las casas de los ricos aguaba la leche.

60 Informante anónimo $\mathrm{n}^{\circ} 3$ del público asistente al Teatro del Círculo Cultural Barracas. Entrevista realizada por mí, el 3 de julio de 2004, Buenos Aires.

${ }^{61}$ Informante anónima ${ }^{\circ} 4$ del público asistente al Teatro del Circulo Cultural Barracas. Entrevista realizada por mí el 3 de julio de 2004 , Buenos Aires.

62 ECO, Humberto: Obra Abierta, Barcelona, Ariel, 1984, pp. 88-89. 
Basta recordar la consideración que en la Retórica de Aristóteles tiene el teatro, género literario catártico por antonomasia; la narrativa es un género grupal, pero se lee a solas y la lírica es un género íntimo. Sin embargo, el teatro "desnuda" la grandeza y las miserias del ser humano y las muestra a todo aquel que asiste a la representación, el cual puede identificarse o no, pero siempre identificará a alguien conocido.

Ver al Grupo Catalinas Sur o al Círculo Cultural Barracas, dos portentosos grupos dignos de un estudio antropológico, resulta siempre un bálsamo curativo.

Porque entre otras cosas, enseñan que estar juntos compartiendo la misma situación social, política, ect., es decir el individuo formando parte de la masa -no el individuo solo luchando por recuperar su identidad-, genera milagros, cura depresiones y mueve montañas.

\section{EL GRUPO CATALINAS SUR EN EL BARRIO DE "LA BOCA"}

El Grupo de Teatro Catalinas Sur nació en un año emblemático para la ajetreada historia argentina, en julio de 1983, de la Asociación Mutual del barrio Catalinas Sur de la Boca surgió la idea de brindar talleres a los vecinos y para ello se convocó al teatrista Adhemar Bianchi63. Es cierto que la Asociación ya venía desarrollando actividades comunitarias en el marco de la Cooperadora de la Escuela $\mathrm{n}^{\circ} 8$ Carlos Della Pena, como forma de resistencia y fortalecimiento del sentido solidario, y aunque la misma se había visto saboteada durante la intendencia de Cacciatore $^{64}$, la Asociación encontró el momento de reagruparse y de buscar en el teatro, la posibilidad de desarrollar una forma vital de expresión con el barrio y la comunidad.

Adhemar Bianchi ${ }^{65}$ propuso la creación de talleres de teatro para hacer en la calle, y se eligió como espacio de reunión la Plaza Islas Malvinas ubicada entre las calles Gaboto, Pedro de Mendoza, Arzobispo Espinosa y 20 de septiembre del porteño barrio de La Boca; como protagonistas, fueron elegidos los propios vecinos.

Así nació la agrupación fundadora, que por entonces se denominó Grupo de Teatro al Aire Libre Catalinas Sur. Pero damos la palabra a una vecina-actriz que aún continúa desde sus inicios, Cristina Paravano, para que sea ella quien nos cuente los comienzos del Grupo:

"Bueno, yo vivo en Catalinas Sur hace ya treinta y pico de años, un barrio de monoblocks (edificio de pisos o departamentos de poca envergadura constructiva); aquí nosotros teníamos una Mutual de Padres que en la época de la Dictadura fue echada del colegio, pero seguimos funcionando haciendo cuestiones edilicias, mantenimientos, exposiciones de pintores de la zona, proyección de películas, hasta que, cuando en 1982 empezaron a aparecer los primeros atisbos

63 BIDEGAIN, Marcela: “'Catalinas Sur y El Fulgor Argentino”, al rescate de la memoria para la construcción de la utopía" en DUBATTI, Jorge (coord.): El teatro de grupos, compañías y otras formaciones (1983-2002). Micropoéticas II. Ed. Centro Cultural de la Cooperación, Buenos Aires, 2003 pág. 127-28.

${ }^{64}$ El brigadier Osvaldo Cacciatore, intendente de la ciudad de Buenos Aires en los años de la dictadura militar, decidió la construcción de ocho autopistas, pero al final sólo se concretaron la Perito Moreno y la 25 de Mayo, cuyo costo faraónico fue financiado con deuda externa avalada por el Tesoro Nacional. Para hacerlas, Cacciatore expropió y derribó cientos de casas y dividió barrios, causando un daño irreparable al paisaje urbano. Además, por su construcción se pagó un sobreprecio de varios millones de dólares. Sobre esta temática y el efecto trágico que tuvo para el barrio de Barracas, trata la obra Zurcido a mano del Grupo de Teatro Barracas.

65 Adhemar Bianchi, director del Grupo de Teatro Catalinas Sur, lleva 22 años de experiencia en el campo del teatro barrial o comunitario. Nacido en Montevideo (Uruguay) en 1945, se formó en la Escuela Municipal de Arte Dramático Margarita Xirgu, el grupo Sesenta y Cinco y en el Teatro Circular de Montevideo donde fue actor, docente y director. Se estableció en Buenos Aires en 1973, es fundador y director del Grupo de Teatro Catalinas Sur y coordina y dirige grupos y talleres de teatro comunitario, en diferentes puntos del país. Es una persona sumamente cordial y amable, que en todo momento nos facilitó el trabajo permitiéndome la grabación de las obras y entrevistas. 
de democracia hicimos talleres y entre ellos, un taller de teatro; esto fue a fines del 82. La profesora dijo en el 83 que no le convenía, pero Mónica, una integrante del grupo nos dijo que conocía un uruguayo, director de teatro y amigo de ella, radicado en la Argentina, cuyas hijas iban al colegio del barrio y que quería hacer un espectáculo, trabajar teatro pero distinto, no el teatro tradicional, sino con vecinos y en la plaza.

A míme interesó mucho, yo estuve en una reunión y después se lo transmití a mis otros compañeros de la Mutual; tuvimos una primera reunión donde muchos de nosotros se mostraron un poco asustados ya que no había costumbre de trabajar en la plaza. Veníamos de una dictadura, además había gente de todo tipo en ese grupo.., había maestros, gente joven, un ingeniero... un ejemplo, Luis, un ingeniero de informática de Naciones Unidas, que estaba un poco asustado y decía: “¿Yo?.. ¿ a la plaza? a jugar...solamente” y Luis, al poco tiempo, el 9 de julio de 1983 cuando fue nuestro bautismo de fuego, apareció en la plaza en una de las tradicionales "choriceadas" de la Mutual, encabezando un desfile, con una gran capa y una galera...

$Y$ bueno, a partir de ahí empezamos a funcionar, con altos y bajos, ¿no es cierto?.., tuvimos nuestro primer espectáculo sobre el Siglo de Oro español, lo estrenamos en 1983, habíamos conseguido prestado un vestuario de época ; fantástico! y entramos a la plaza como los juglares de la Edad Media, con un carro y un caballo de verdad; entre nosotros había una señora mayor, que después con el tiempo cumplió los 90 sobre el escenario en el teatro, que se los festejamos en una de las funciones de "Venimos de muy lejos" ;con una torta de utilería!., y bueno, eso fue un éxito; me acuerdo que con ese espectáculo sobre el Siglo de Oro Español era la primera vez que había teatro en la plaza) los vecinos estaban encantados, nosotros "chochos", porque estaba la plaza llena cuando llegamos.., fue muy lindo, aparte los textos tenían que ver con la censura y con todo lo que habíamos vivido, fue una cosa preciosa.

Después en el año 1984, había una gran desmoralización y recuerdo la primera reunión, en la que había muy pocas ganas. Y Adhemar saca un libreto en éste caso, una versión de "El Herrero y la Muerte" 66 y nos empezamos a reír, a leerla y leerla y ahí armamos: "El Herrero y la Muerte", y después vino: "Sueño de una noche de verano o Pesadilla de una noche en un con$v_{\text {ventillo }}^{67 ", ~ " E n t r e ~ g a l l o s ~ y ~ m e d i a n o c h e " ~}{ }^{68}$ y algún otro espectáculo hecho por los adolescentes..., y todo en la plaza, siempre en la plaza de nuestro barrio.

Hasta 1990 cuando estrenamos "Venimos de muy lejos ${ }^{69 "}$, que fue un hito en la trayectoria del grupo, ahí de pronto nos acordamos..., ( entra otra actriz en el vestuario) Alicia que acaba de entrar, también seguro que se acuerda y se emociona, con el estreno de Venimos de muy lejos en la Plaza Islas Malvinas..; yo por ejemplo, represento en el escenario la historia de mi bisabuela "tana", Clementina Postadoni de Bozzani, cuyo marido vino a la Argentina para abrirse camino, y un día dejó de escribirle vaya a saber por qué

66 El herrero y la muerte, es obra de Jorge Curi y Mercedes Rein, con dirección de Adhemar Bianchi. Se estrenó en 1984 en Plaza Malvinas, y se presentó por diversas plazas y parques de la ciudad;es una versión "gauchesca"sobre la antigua leyenda, presente en distintas culturas, de un hombre de pueblo que, en duelo con la muerte logra engañarla. GRUPO CATALINAS SUR: Historia de una Utopía. Ed. El Grupo de Catalinas, Buenos Aires, 2001. Pág.24

67 Pesadilla de una noche en el conventillo, es una versión libre de "Sueño de una noche de verano" W. Shakespeare, que bajo la dirección de Adhemar Bianchi se estrenó en 1986 en la Plaza de Malvinas y en otras plazas y parques de la ciudad de Buenos Aires. En ella, los duendes no habitan el bosque sino el patio de un conventillo, y no eran gnomos sino personajes del arrabal y del tango.

68 Versión libre de la obra de Mercedes Rein y Jorge Curi, basada en "Los casos de Juan" de Bernardo Canal Feijoo. Estrenada en 1988 en la plaza Malvinas en la Boca, se presentó además en otros parques y plazas de la ciudad. Ibídem: GRUPO CATALINAS SUR: Historia de una Utopía.....pág.22.

69 Es una creación colectiva dirigida por Adhemar Bianchi y estrenada en 1990 en la plaza Malvinas del Barrio de Catalinas Sur; se repone todos los años, siempre con impresionante éxito de público. Venimos de muy lejos está realizada desde el afecto hacía los antepasados inmigrantes, sin pretensión histórica ni antropológica. Los personajes y situaciones son ficciones a partir de la imaginación colectiva. Esto no quita que en la obra, afloren fragmentos de personajes, historias reales y leyendas de la gente de la Boca. Es un homenaje a los "gringos" que les precedieron. Esta obra se escenificó en diversas provincias: Misiones, Santa Fe, Entre Ríos e incluso fue llevada a Chile, al Teatro el Grec de Barcelona en 2001 y al $1^{\circ}$ Festival Internacional de Teatro de Vecinos, de Buenos Aires. Ibídem: GRUPO CATALINAS SUR: Historia de una Utopía. Pág 13-4. 
motivos. Clementina tomó entonces una decisión aventurada: vendió todo, y con sus cinco hijas inició el largo viaje que, felizmente, concluyó con el reencuentro. En la familia el hecho se hizo leyenda, y es la que hoy se cuenta en el espectáculo con algunas variantes. Para mí, fue un reencuentro con esa historia familiar y un privilegio recordarla cada vez que salgo al escenario. Nunca hubiera imaginado Clementina que iba a seguir existiendo después de tantos años.

Nosotros, algunos...por lo menos yo, decíamos: "Ay, pero la gente se va a aburrir”, no teníamos ninguna visión al respecto; bueno, quedamos perplejos con el resultado, me acuerdo que hablamos tres días seguidos del tema. Nos juntamos al día siguiente que no teníamos función en la plaza, y seguíamos hablando y hablando del tema y de la emoción que habíamos sentido. Bueno, "Venimos de muy lejos", es un espectáculo que no está en cartel, pero sí en repertorio, y lo hemos puesto en escena muchísimas veces, y siempre con mucho éxito de público; ;una emoción!.,lo llevamos a varias provincias, estuvimos en Chile y nos permitió que se acercara mucha gente al grupo que se fue llenando de jóvenes, y gente que, la mayoría, tienen las mismas banderas nuestras; el ser productores de cultura y no solamente consumidores, de llevar adelante nuestras utopías; es una manera de resistir a lo que es el individualismo que se quiere apoderar de nosotros ¿no es cierto? y esto es una demostración de que el trabajo en conjunto, comunitario, lo puede vencer..,se pueden hacer cosas poniendo un poquito de cada uno, poniendo un poquito de arte, porque todos lo tenemos. Es reivindicar el arte que todos tenemos adentro poniéndolo en el escenario, y por supuesto, teniendo un cocinero que lo arma, en este caso, el director y sus colaboradores; y así aparecen cosas como "Venimos de muy lejos", "El Fulgor Argentino 70 ", cosas donde nuestro principal orgullo, éxito, o virtud, es sentir que nos comunicamos con los espectadores que nos vienen a ver, o sea lo que nosotros queremos decir, el espectador lo recibe. Y eso cuando termina la función y hay un aplauso general del público, uno siente que ha contado algo que quiso contar, y que lo ha contado bien, poniendo el alma en el escenario, de tal manera que los demás lo recibieron de ese modo ${ }^{71}$ ".

En el año 1997 el grupo Catalinas dio un paso fundamental: alquiló un galpón (un espacio en forma de nave industrial), que luego compró en agosto de 1999, acondicionándolo como su casa, "Nuestra plaza techada" como lo llaman los miembros del grupo.

El llamado "Galpón de Catalinas" está ubicado en la Avenida Benito Pérez Galdós 93, en pleno corazón del barrio de La Boca. Por su parte, su director Adhemar Bianchi, evoca esos tiempos:

"La autopista nos provocó un problema grave, con el ruido no se podía hacer teatro en la plaza, y ya teníamos un local chico, cada vez más chico para los ensayos, entonces buscamos un galpón dónde guardar cosas, hacer fiestas, funciones. Este galpón estaba cerrado, un día un señor salía de aquí, y lo hinchamos tanto, que al final nos lo alquiló, con el compromiso

70 Se estrenó en noviembre de 1998 y estuvo en cartel durante los años 1999 a 2001en el Galpón de Catalinas, con impresionante éxito de público, por lo que todos los años se representa nuevamente durante algunos meses. Es una obra de creación colectiva que, bajo la dirección de Adhemar Bianchi y Ricardo Talento, tiene 100 actores en escena, orquesta, grandes muñecos, tanques, cañones, y demás utilerías que dan vida a este espectáculo. La visión de los " 100 años de fulgor argentino"es un intento de memoria que no implica análisis académico sobre los hechos, sino el rescate de los hitos que han quedado en la memoria colectiva. La obra sigue la trayectoria de un Club social de 1930, que abre sus puertas para los bailes; el golpe contra Irigoyen interrumpe los festejos y de ahí en adelante, el salón de baile es un reflejo de los avatares de la historia argentina. Los asistentes se mueven al compás de los distintos ritmos bailables que, según van pasando los años interpreta la orquesta. El baile se interrumpe cuando la historia lo permite, y los enfrentamientos y golpes militares truncan la fiesta que permanentemente lucha por reiniciarse, mientras la historia sigue su curso hasta 2030.

71 Ibídem: Entrevista realizada por mí a Cristina Paravano, el 16 de agosto de 2004 en los camerinos del Galpón de Catalinas, en Buenos Aires. 
de venderlo; hicimos una hipoteca y la pagamos mensualmente durante dos años, fueron 180.000 dólares en total ${ }^{72}$ ".

Sobre sus paredes, el maestro Omar Gasparini, miembro del grupo, diseñó y dirigió la realización de un gran mural de cerca de 50 metros, que se completó con el trabajo instalado sobre el frente, diseñado y esculpido por las artistas plásticas Andrea Bustamante, Andrea Agüero y Valeria Vizioli ${ }^{73}$.

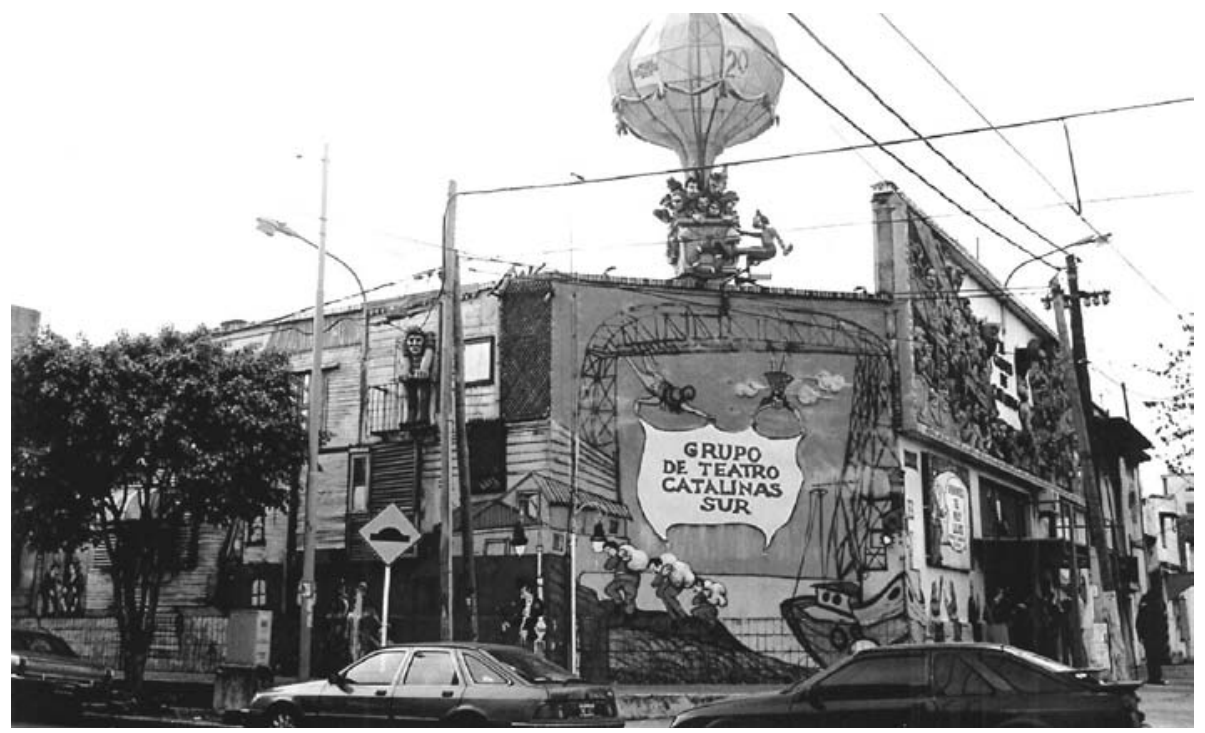

El Galpón de Catalinas, en la Calle Benito Pérez Galdós 83, del Barrio de La Boca (Buenos Aires) el día 15 de agosto de 2004. Foto realizada por mí. Desde lejos se divisa el teatro, con su globo aerostático que, como mascarón de proa, orienta a los espectadores. Teatro estable donde representa este grupo, que es pionero en la actividad del teatro comunitario. El edificio hace esquina y todo su exterior está decorado con figuras y escenas grotescas, que representan el universo popular de los compadritos y conventillos de la Boca, realizado en relieve y con figuras que sobresalen a modo de escenografía sobre la fachada colorista.

$\mathrm{Al}$ ingresar a la antesala, llena de carteles y recortes de prensa, que muestran las críticas siempre elogiosas que han recibido, hay un pequeño escaparate en el que se venden algunos recuerdos del grupo tales como postales, carteles y CD's de música de algunos de los montajes. A la derecha del ingreso, junto a la boletería o taquilla de las entradas, hay un cartel que dice: Socios Utópicos, allí se inscriben quienes quieran colaborar como sostenedores del grupo, por la cantidad de 5 pesos mensuales (algo menos de 1,5 euros) y esta categoría faculta el poder acceder gratuitamente a todos los espectáculos que presenta el grupo.

72 Ibídem: Entrevista al director del Grupo Catalinas Sur, Adhemar Bianchi, nacido en 1945 en Montevideo. Entrevista realizada por mí, el 17 de agosto de 2003 en el Galpón de Catalinas, en el barrio de La Boca.

73 Ibídem: BIDEGAIN, Marcela: "Catalinas Sur y El Fulgor Argentino, al rescate de la memoria para la construcción de la utopía” en DUBATTI, Jorge (coord.): El teatro de grupos, compañías y otras formaciones (1983-2002). Micropoéticas II. Ed. Centro Cultural de la Cooperación, Buenos Aires, 2003 pág. 129. 
Esta forma de ayuda ha encontrado una excepcional respuesta entre los espectadores, ya que hasta 2001 contaban con aproximadamente 1000 amigos utópicos, que con su aporte mensual son un apoyo muy importante para consolidar los proyectos ${ }^{74}$.

En el interior, gradas de sillas distribuidas de manera ascendente, contienen capacidad para trescientos espectadores. Si bien es cierto que la mayor parte de la producción de Catalinas Sur se presenta en el Galpón, el grupo no olvida la calle y cada cierto tiempo vuelven a ella ${ }^{75}$, al lugar donde tienen su origen. Será por esa nostalgia, que sus puestas en escena mantienen el espacio de representación rectangular, con el lugar para los espectadores a ambos costados de la escena en gradas ascendentes y como arte constitutiva del cuadro visual. Se utilizan también todas las dimensiones, como la altura, con efectos de sorpresa. En esa democracia de expectación, todos por igual, pueden ver lo mismo desde cualquier butaca.

La obra “El Fulgor Argentino Club Social y Deportivo" estrenada en noviembre de 1998 y en cartel hasta 2001, fue la mecha que encendió, en medio de la crisis, la inquietud de otros colectivos por seguir los pasos del grupo Catalinas Sur.

Esta obra, que es un grandioso espectáculo teatral, recrea cien años de historia argentina (1930 a 2030) vista a través de las veladas bailables de un club de barrio. Cada uno de los hitos de la historia, se presenta con un despliegue de signos conocidos, esto es: el ritmo bailable característico de cada época (tango, milonga, pasodoble, twist, rock, cumbia), la moda en la vestimenta de cada década, las costumbres, los hábitos y los enfrentamientos varios.

La reconstrucción se da como ilustración, para entender que se debe aprender o recuperar la memoria para evitar los errores del pasado.

En esto radica el carácter pragmático de este tipo de poética, que garantiza la efectividad de la comunicación de su mensaje.

En un intento de volver a reubicar las tradiciones, se rescatan las formas populares como una auténtica revalorización del folklore. En el centro de la barra del bar y a lo largo de toda la obra, está omnipresente la radio, que trasmite noticias, decretos y comunicados oficiales; el radioteatro, la canción popular, la publicidad comercial y proselitista, todos los lenguajes y géneros presentes en la memoria colectiva, van desfilando para ayudar a rememorar cada época.

Claro que a la hora de llegar a los momentos más próximos del presente, y cuando las heridas todavía no están cicatrizadas, se elige el formato de la noticia atravesada por la sátira y la ironía de la murga, la expresión de las ollas y los bombos en las manifestaciones populares, para que de alguna manera se pueda transitar con menos dolor los episodios más recientes. Reproducimos aquí una de las canciones titulada "De vuelta el fulgor argentino": ${ }^{76}$

Es la hora, es la hora,

Que pasó dígame.

es la hora de elegir,

Llegó la desocupación

74 Ibídem: GRUPO CATALINAS SUR: Historia de una Utopía. Pág 31.

75 Por ejemplo su último montaje "Argentina año verde", pastorela porteña con dirección de Adhemar Bianchi y Cristina Paravano, fue estrenada el día 25 de diciembre de 2002 en la Plaza Malvinas, en el barrio de La Boca, donde surgió el grupo. En ella participaron los nuevos integrantes del grupo que se incorporaron al proyecto en 2002, y los talleres de circo y títeres. La Pastorela, es una fiesta navideña tradicional mexicana. En distintos países y culturas se representan las pastorelas adaptándolas, según lo que se quiera contar. Aquí está ambientada en una Argentina del año 2030, en la que ya no existen las profesiones y lo único que hay son cartoneros, viejos titiriteros y cirqueros. Grupos desesperanzados en una Argentina donde no nacen más niños. El inesperado nacimiento de un niño, renueva la esperanza en una Argentina destruida y permite que la gente vuelva a creer en el futuro. Accesible a través de : http://www.catalinasur.com.ar/ [junio, 2005]

76 Aunque la obra se estrenó en 1998, se va actualizando a tenor de la coyuntura. Programa de mano de la función de El Fulgor Argentino Club Social y Deportivo. 1930-2030. Creación colectiva. Dirección Adhemar Bianchi y Ricardo Talento. 
se acabó la dictadura

volveremos a reír.

La democracia está y a cantar

la democracia está y a bailar.

La demo, democracia está y a cantar.

Hay una deuda pendiente

y la queremos cobrar.

La democracia está y estará

la democracia está y estará

la demo, democracia está y estará

este pueblo la defiende

y la va a hacer respetar.

No crean que los milicos

solitos van a joder

¡cuidado con los magnates

que manejan el poder;

Si éste es el que ganó

estamos sonados

aunque nadie reconozca

haberlo votado.

Tiene tantos familiares

$\mathrm{y}$ amigos para dar de comer

estoy seguro que el salariazo ${ }^{78}$ es para él.

Que va a pasar

yo no lo sé.

Qué va a pasar

vamos a ver.

Si esto es primer mundo

yo prefiero ser un vagabundo.

No seas anticuado,

hay que competir en los mercados.

Que pasó dígame

Llegó la modernización
Y vendimos el petróleo, el teléfono, el gas y la luz. ¡Socorro!

Presentador-Chupete ${ }^{77}$ :

-y dicen que soy aburrido...

No importó

que fuera aburrido o alegre

que usara campera o sacón

nos pidió un voto de confianza

y se lo dimos.

Qué pasó,

que a este tipo nadie lo votó

viene a completar su destrucción

porque todos lo conoceremos

Hijo del fondo.

Somos del pueblo

que ya está repodrido

de oír tantas mentiras

en boca del poder.

Hoy en las calles

resuena nuestra bronca.

Tengan mucho cuidado

con lo que van a hacer.

Hay nuevo presidente.

Rumor entre la gente.

Muchas preguntas y expectativas también.

Si hace lo que dijo

y pone rumbo fijo

defenderemos nuestros derechos con él.

Porque una patria más humana,

justa, libre y soberana

es lo que todos queremos tener también

No faltan todo tipo de recursos: máscaras, disfraces, letreros y estandartes, muñecos gigantes, que en realidad, hablan o describen un lenguaje muy estilístico, dado que incluye lo ilógico en nuestra comprensión cotidiana, para abrir así, nuestra percepción de la realidad. ${ }^{79}$

Es parte de la fantasía del espectador, imaginar el movimiento de tan increíble maquinaria artística cuando está fuera del alcance de la mirada, el valorar la capacidad de sincronización para que, los más de cien actores mantengan en cada escena el adecuado ritmo. Mención aparte, merece la explosión de color que genera el vestuario en cada una de las escenas de conjunto. Son seiscientos los trajes que están dispuestos detrás de la escena, para

\footnotetext{
Chupete es el nombre con que se conocía a De la Rúa, porque empezó muy joven en la política.

78 Consigna de Menem en su primera campaña electoral: revolución productiva y salariazo.

79 Ibídem: BIDEGAIN, Marcela: "Catalina Sur y El Fulgor Argentino, al rescate de la memoria para la construcción de la utopía” en DUBATTI, Jorge (coord.): El teatro de grupos, compañías y otras formaciones (1983-2002). Micropoéticas II. Ed. Centro Cultural de la Cooperación, Buenos Aires, 2003 pág. 134.
} 
que, en el menor de los casos, cada actor cambie cuatro veces como mínimo de vestimenta en cada función. Son alrededor de 120/30 vecinos-actores los que en escena narran, lo que los espectadores desde la platea podrían contar. Porque se trata de una creación colectiva, movilizada por la firme convicción de que el teatro es la mejor forma de comunicación, y que por medio del mismo todos pueden expresar y rescatar su pasado.

De allí la extraordinaria empatía que logran los actores con el público en cada función.

Afortunadamente este tipo de fenómenos en los que la realidad nunca está ausente, se propagan rápidamente y a gran velocidad de contagio.

Así es como Adhemar Bianchi, se enorgullece de compartir su experiencia, acercar el teatro a diferentes comunidades y proveerlos de elementos para, que sean protagonistas de sus problemáticas comunes.

Desde 2001 como el Grupo seguía creciendo, alquilaron el espacio contiguo al Galpón donde actualmente funcionan: oficinas, salas de ensayo, camarines, el Taller de realización plástica y escenográfica que lideran Omar Gasparini y Alfredo Iriarte, y el de títeres que dirige Ximena Bianchi, hija de Adhemar.

Allí pueden verse títeres y todo tipo de máscaras, muñecos y atrezzo, realizados con las más diversas técnicas y materiales. Una muestra de la amplia gama de recursos escénicos que se emplean en los diversos montajes teatrales del Grupo Catalinas Sur; en las tres imágenes, diversos tipos de títeres. Fotos realizadas por mí, en el galpón anexo al teatro, que sirve de almacén y donde se realizan los talleres.

El Centro se hace cargo del desarrollo de talleres de teatro, dramaturgia, radioteatro, seminarios de dirección, iluminación, historia barrial, títeres, máscaras, escenografías, vestuario, malabares, trapecio, zancos, fabricación de instrumentos, coro, candombe, murga, tango, flamenco, acrobacia y equilibrio en alambre, entre otros. Estos talleres, lejos de concretarse para fines individuales, cobran sentido en función del esfuerzo conjunto que se materializa en sus diversos espectáculos.

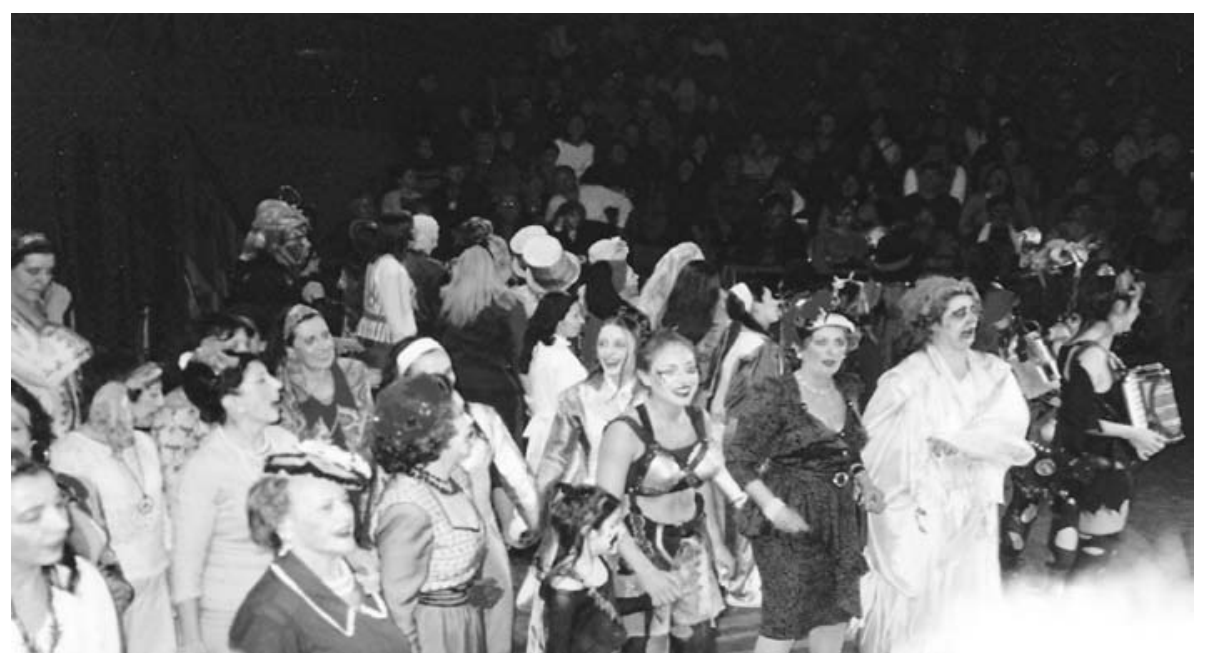

Una escena del "Fulgor Argentino" actuando en el Galpón de Catalinas Sur, la obra de Adhemar Bianchi y Ricardo Talento en la que participan entre 120/130 vecinos-actores, y que es un repaso de los avatares de la historia argentina, desde los año 30 hasta el futuro. Puede observarse además de la cuidada puesta en escena de vestuario y cómo hay actores de todas las edades. Foto realizada por mí el 17 de agosto de 2003. 
En 1993, el Grupo, realiza un convenio con la dirección de Promoción Cultural de la Secretaria de Cultura de la Ciudad, por el cual su Centro recibe el apoyo del programa: Cultura en los Barrios. Ese es el único aporte oficial que recibe el Catalinas y con el cual paga los honorarios a los profesores.

Hoy, ya son tres las generaciones que conforman la agrupación. Trescientas personas suman los integrantes, entre los que se cuentan hijos y padres que encontraron en Catalinas un espacio para compartir intereses.

Algunos ya se desempeñan como directores de talleres, porque esa es la intencionalidad que anima al grupo: expandir y transmitir la experiencia. De los primeros integrantes deben quedar unas seis o siete personas, según nos confirman Adhemar y Cristina Paravano, entre los cuales se encuentran ambos. Así nos lo cuenta Adhemar Bianchi:

“Ahora hay muchos jovencitos, hijos de los actores, hay nietos..., a veces trabajan tres generaciones de la misma familia. Durante años entraban directamente, después hubo problemas de organización, y de acuerdo al convenio que hicimos con la municipalidad para el pago a los profesores, los talleres se abren en el mes de abril, cuando lo hacen los centros culturales. No hacemos audición, charlamos, les contamos, y se quedan los que quieren, sin límite de edad, trabajan durante un año en los talleres, después se integran en los espectáculos 80 "

Entre sus miembros, el Catalinas tiene a ingenieros, psicólogos, maestros, amas de casa, jubilados, estudiantes, músicos...

“Al principio en nuestro teatro no había escuelas, los cómicos empezaban siendo partiquinos; en nuestro caso el núcleo básico al inicio fue con gente de treinta y cinco, cuarenta años, sin vergüenza de estar probando cosas. Ahora en el elenco hay gente de La Boca, de Barracas, de San Telmo, y de barrios más lejanos. Somos un teatro de vecinos que toma esto con el concepto materno, en el sentido francés de la palabra, amador de lo que hace. Nuestros niños se entusiasmaron con el teatro, empezaron aquí, hoy están cerca de los treinta años y son profesores de títeres, de circo, tenemos trapecistas, malabaristas, los llaman de otros lados, son estupendos, con una formación realmente buena, el estudio por un lado, y por otro, la práctica $^{81}$ "

Y así el trabajo de estos diversos talleres fue dando sus frutos: el del taller de circo, se plasmó en el espectáculo Sudestada ${ }^{82}$, un Sainete circense estrenado en 2002 en el galpón, y en plazas de la ciudad durante el año 2003. Constituye el primer trabajo integral del taller de circo, del Grupo de Teatro Catalinas Sur.

80 Ibídem: Entrevista al director del Grupo Catalinas Sur, Adhemar Bianchi, nacido en 1945 en Montevideo. Entrevista realizada por mí, el 17 de agosto de 2003 en el Galpón de Catalinas, en el barrio de La Boca.

81 Ibídem: Entrevista a Adhemar Bianchi, director del Grupo Catalinas Sur, el 17 de agosto de 2003 en el Galpón de Catalinas, en el barrio de La Boca.

82 Con dirección de Pedro Palacios y Bruno Gagliardini, "Sudestada", es un espectáculo teatral basado en las técnicas del circo(o las técnicas del circo al servicio de un espectáculo teatral) donde se cuentan con ritmo de sainete circense, historias de las inundaciones en los conventillos de La Boca. La lucha tragicómica de los vecinos malabaristas por salvar sus pertenencias, los bomberos-payasos subidos a los techos salvando gatos en peligro, los amantes trapecistas que bailan su tango en las alturas, el ladrón equilibrista que cruza los balcones y los policías payasos tratando de atraparlos, los conflictos entre vecinos malabaristas por la limpieza posterior a la inundación...todo al compás de canciones "tanas" y "gallegas" que ejecuta la banda de músicos, y de la ternura de los personajes y situaciones. 
"Sus directores, eran integrantes "niñitos" en la primera época, que se formaron como actores y cirqueros dentro del Grupo Catalinas. Y también como sucede en "La niña de la noche", es fantástico verlos crecer presentando un espectáculo de Catalinas, donde el teatro es comunicación y no engolamiento y donde, las destrezas personales están al servicio del resultado, y el éxito del resultado lo da la fuerza de lo colectivo ${ }^{83}$."

El del taller de títeres, se ha materializado en dos espectáculos: en la varieté titiresca "La niña de la noche" ${ }^{84}$ y el trabajo más reciente en 2004 de "Osos o no sos" 85 " con dirección de Ximena Bianchi, otra integrante de la segunda generación. Y como nos dice Adhemar Bianchi:

"Tenemos una diversificación muy grande, en el sentido de que, por cantidad de gente y por cantidad de años tenemos muchas líneas de trabajo; entonces seguimos trabajando sobre la historia, porque ese es un tema fundamental nuestro, pero por ejemplo, ha crecido mucho todo lo que es el trabajo con títeres; ahora hay un espectáculo de títeres para adultos que se va a armar, y Catalinas, después del San Martín y de Libertablas, puede tener veinte titiriteros en la producción de muñecos, hechos todos en nuestra fábrica ${ }^{86}$ "

Las creaciones de este conjunto de vecinos, mantienen el criterio callejero y popular, bebiendo en las fuentes de la murga, el sainete y el circo criollo, y sus integrantes, como dice la canción de presentación del espectáculo "La Catalina del Riachuelo '98", siguen siendo quienes son, sin más:

"Ya salimos en los diarios, en la tele y en la radio, pero no nos la creímos, seguimos siendo $\operatorname{vecinos}^{87 ”}$.

83 Varieté titiritesca estrenada en 1998 en El Galpón de Catalinas, en colaboración con la Escuela de Música Popular de Avellaneda (Prov. de Buenos Aires). Primer trabajo integral del Taller de Títeres del Grupo de Teatro Catalinas Sur. Sus integrantes representan lo que llamamos la "segunda generación de Catalinas", ya que el grupo de trabajo (titiriteros, realizadores, iluminadores, la directora y el compositor) son hijos de integrantes de la "primera época", demostrando que estos 18 años de trabajo en el campo de teatro popular, generaron un espacio donde padres e hijos confluyen humana y artísticamente. Este proyecto comienza, como un manojo de imágenes infantiles que la directora rescató de su memoria, relatos, fábulas, cuentos. Entre todos ellos "La Niña que iluminó la Noche" de Ray Bradbury, fue el que surgió con más claridad. No es este espectáculo, ni una versión, ni una adaptación de este cuento, es mas bien un canto a la noche y a la magia de sus habitantes cotidianos, que aparecen con sus canciones. Este espectáculo permaneció en cartel desde 1998 a 2001.

84 Varieté titiritesca estrenada en 1998 en El Galpón de Catalinas, en colaboración con la Escuela de Música Popular de Avellaneda (Pcia. de Buenos Aires). Primer trabajo integral del Taller de Títeres del Grupo de Teatro Catalinas Sur. Sus integrantes representan lo que llamamos la "segunda generación de Catalinas", ya que el grupo de trabajo (titiriteros, realizadores, iluminadores, la directora y el compositor) son hijos de integrantes de la "primera época", demostrando que estos 18 años de trabajo en el campo de teatro popular, generaron un espacio donde padres e hijos confluyen humana y artísticamente. Este proyecto comienza, como un manojo de imágenes infantiles que la directora rescató de su memoria, relatos, fábulas, cuentos. Entre todos ellos "La Niña que iluminó la Noche" de Ray Bradbury, fue el que surgió con más claridad. No es este espectáculo, ni una versión, ni una adaptación de este cuento, es mas bien un canto a la noche y a la magia de sus habitantes cotidianos, que aparecen con sus canciones. Este espectáculo permaneció en cartel desde 1998 a 2001.

85 Espectáculo de títeres para toda la familia, con 20 manipuladores y más de 35 títeres con diferentes técnicas de manipulación. Versión libre del cuento de Frank Tashlin "El oso que no lo era".La historia cuenta las desventuras de un oso, que obligado a vivir como un hombre en un mundo al cual no pertenece, pierde así su identidad.

86 Ibídem: Entrevista a Adhemar Bianchi, director del Grupo de Teatro Catalinas Entrevista realizada por mí, el 15 de agosto de 2004, en el Teatro Catalinas Sur.

87 Ibídem: GRUPO CATALINAS SUR: Historia de una Utopía........ Pág 6. 
El Grupo Catalinas Sur, antes que una compañía teatral es la materialización perfecta de un proyecto cultural. Sus integrantes pertenecían a una generación que creía en el mundo del trabajo, la justicia social y esencialmente, en el valor de la solidaridad. Pero pasó la devastadora pisada globalizadora con el vacío como modelo, las desigualdades cada vez más notorias, el desmantelamiento del Estado y de los servicios sociales (en pro de la frivolidad), la devaluación de la cultura y la educación, y sin embargo, el grupo hizo frente a los embates y sobrevivió, y prueba de ello son los numerosos espectáculos que han realizado desde su conformación y los que siguen creando aún, como también son cada vez más los premios que reciben en reconocimiento a tanta tenacidad y vocación de trabajo. ${ }^{88}$

Catalinas Sur sigue creciendo sin barreras generacionales, divulgando su arte y extendiéndolo a cuantos quieren apostar por esta forma de comunicación y también de resistencia; porque Catalinas Sur no se mantiene ajena a la coyuntura que el país vive hoy, en momentos en que la gente volvió a ocupar el espacio público en los clubes de trueque, cacerolazos, piquetes, asambleas barriales y organizaciones estudiantiles.

Como fenómeno de autoafirmación de identidad de aquellos que se ponen al frente, ante la falta de representatividad y el fracaso de la clase política actual, esta agrupación teatral, reivindica su impronta o marca de origen: la firme convicción de que sólo una sociedad puede cambiar, con el trabajo conjunto y comunitario.

Con esa convicción muchos jóvenes se siguen uniendo al grupo y mantienen altos los objetivos, y a través de esta consigna que lo caracteriza, distingue e identifica, el Grupo Catalinas Sur se mantiene en plena creación y más vivo que nunca, como parangón y ejemplo para otros grupos de teatro comunitario. Así nos lo deja de manifiesto su director cuando le preguntamos por los nuevos proyectos:

“(...) Estamos también ahora con un espectáculo tipo carnaval, no de murga, sino de lo que nosotros llamamos parodistas, que es una forma de revista que ha nacido en el Uruguay y que tiene que ver con la situación política coyuntural; o sea que la ironía es parodismo, porque parodia la realidad y con humor, enfoca problemáticas y temas que tienen que ver con el poder y con lo social. También estamos trabajando mucho en lo que es circo, y del lado del circo, hemos empezado a programar con organizaciones de barrio, $u$ organizaciones sociales que tiene la visión de convertir los barrios en mundos nuevamente vivos (desde los microemprendimientos y las cuestiones comunitarias) y que tiene como uno de los problemas principales poder incluir a los jóvenes, a los adolescentes. Entonces nosotros ayudamos por el lado del circo (entendido el circo como un lenguaje artístico donde le agregamos el canto y un montón de cosas más) y también estamos trabajando con niños y adolescentes, en todo lo que es trabajo en arte, pero también elaboramos títeres.

Además estamos pensando dos espectáculos nuevos. Uno es una historia de la cultura, a través de la vida de Quinquela Martín, el más destacado pintor de la Boca, y de otros pintores de línea popular, porque siempre hubo como dos planteos culturales en la Argentina; y a través

88 En 1996 recibieron la mención por trayectoria, del Premio María Guerrero y el homenaje a la trayectoria, del Premio ACE. Adhemar Bianchi, recibió en el Festival de Río Ceballos 98, el Premio Reconocimiento a la Trayectoria Teatral. El espectáculo El Parque Japonés, fue nominado para el Premio ACE. En 1998 obtuvieron el Premio Siglo XXI, mención especial por el rescate de la historia y las tradiciones populares, otorgado por la Revista GETEA, de la Facultad de Filosofía y Letras de la Universidad de Buenos Aires. En 1999, la Mención Premio Pepino el 88, para el bienio 1997/1998. También recibieron el Premio Especial Florencio Sánchez 1999, el Premio Blanca Podestá, Mención Especial, otorgado por la Sociedad Argentina de Actores, En el año 2000, la Mención Especial Premios Konex 2001 para la década 1991-2000. En el año 2002, el Premio Clarín Espectáculos 2002 para El Fulgor Argentino. En el año 2003 ,el Premio Trinidad Guevara a la producción teatral y en el 2004 fueron finalista para el premio a las "Artes Creativas" que entrega la World Culture Open, organización internacional con fines pacifistas, que intenta integrar a los pueblos a través del arte y la cultura http://www.catalinasur.com.ar/[noviembre, 2004] 
de ahí, haremos un estudio del tema, con un espectáculo posiblemente de títeres y coros.., también ahora nos vamos a meter con la Historia Argentina, es decir, con la Historia de la Constitución Argentina, y estamos planteándonos todo lo que fue el siglo XIX, digamos desde el 1700 a casi el 1800. Vamos a hacer todo un estudio de cómo se conforma esta Argentina... antes de la Revolución de Mayo; básicamente, la lucha entre lo que es la Liga Federal y el Centralismo Porteño, desde Artigas y todo lo que fue la lucha entre el 10 y el 22 ..., porque la Liga Federal pelea por un lado contra Brasil, por otro lado contra España y también contra Buenos Aires, intentando crear un país mas justo, que no el puerto.., en fin, trabajamos en muchas líneas.

Yo estoy haciendo codirecciones en todos los espectáculos que dirijo yo, pero ya hay tres espectáculos que no dirijo, que dirigen los nuevos, o sea los jóvenes. Estamos ahora planteándonos mucho, algunos seminarios afuera del país y haciendo trabajos. Ahora posiblemente yo viaje a Nueva York y ya estuvimos en Brasil y seguramente habrá otros eventos afuera, donde empezaremos a participar haciendo coproducciones con algún grupo popular de otro lado. Porque ahora si contás los talleres de adolescentes, ( porque ya hay un taller de adolescentes que está haciendo una versión de "Hubo un Rey"), si contás adolescentes y niños, pasan lo trescientos y pico, pero los elencos siempre están en 70,80, 100, 120.., dependiendo de la obra.

Ahora la tendencia es hacer más obras con menos elencos, porque es muy problemático trabajar con ciento veinte personas o más ${ }^{89}$ "

\section{La idiosincrasia del teatro comunitario}

El teatro comunitario constituye uno de los fenómenos culturales más relevantes de los últimos años, cuyos referentes más desatacados son, como hemos mencionado ya, el Grupo de Teatro Catalinas Sur, de La Boca, con 22 años de trayectoria, y Los Calandracas ${ }^{90}$, que nacieron en 1987 y sobreviviendo a la globalización ( que se llevó por delante a numerosos grupos de teatro callejero), consiguieron en abril de 1996, asentarse en su propio espacio, el Circuito Cultural Barracas ${ }^{91}$.

El objetivo fue desde entonces, retransmitir a los vecinos del barrio y su zona de influencia, las técnicas artísticas que les permitieran ser protagonistas de hechos artístico-culturales y, a través de sus propias producciones comunicarse con otros vecinos. Resultado de ello son El Teatral Barracas, que lleva a escena estos últimos años dos obras : "El Casamiento de Anita y Mirko", un evento teatral que recrea una fiesta de casamiento, en donde el público es el invitado; "Zurcido a mano", una cantata barrial en cuatro movimientos, que es una apuesta por la memoria y la historia del barrio de Barracas, con una espléndida puesta en escena; además,

89 Ibídem: Entrevista realizada por mí a Adhemar Bianchi, director del Grupo de Teatro Catalinas, el 15 de agosto de 2004, en el Teatro Catalinas Sur.

90 Los teatreros que originariamente conformaron la agrupación: Ricardo Talento, Corina Busquiazo, Rafael Zicarelli, Ana Postigo y Mariana Brondiano, se conocieron en 1985 en un Seminario de Perfeccionamiento Actoral, que se realizaba en la ciudad de Avellaneda. Dos años después se conformaba el grupo, y una tarde de enero de 1988 hacían su aparición en el Parque Lezama como Los Calandracas, montados en Mamerto, un largo caballo, personaje de su primer espectáculo: Alegro, Manón, Tropo'.!.. Sobre su nombre, nos cuentan los integrantes de Los Calandracas: "La calandraca es la humilde sopa que permitía a los marinos en la antigüedad, llegar a buen puerto cuando se quedaban sin suficientes comestibles. A nosotros ese nombre, nos permite llegar con nuestros sueños a cada uno de los espectadores”,. BIDEGAIN, Marcela: "Los Calandracas, una vocación comunitaria" en DUBATTI, Jorge (coord.) : El teatro de grupos, compañías y otras formaciones (1983-2002). Micropoéticas II. Ed. Centro Cultural de la Cooperación, Buenos Aires, 2003, pág. 299-301.

91 Un galpón de $300 \mathrm{~m} 2$ ubicado en avenida Iriarte 2165, en pleno corazón del barrio viejo de Barracas, en cuyo frente está plasmado por parte del maestro Omar Gasparini, en un impresionante mural, la historia, los personajes y la proyección artística del Circuito Cultural Barracas. Trabajo que fue una ofrenda y prueba de amistad, del vecino grupo Catalinas Sur. Ibídem: BIDEGAIN, Marcela: "Los Calandracas, una vocación comunitaria” en DUBATTI, Jorge (coord.) : El teatro de grupos,....pág.313. 
Los Payasos del Circuito, encuentros mensuales de payasos, con el nombre de "Chalupazo"; el ciclo Teatro para Armar ${ }^{92}$ que el grupo viene desarrollando desde 1989, y la murga Los Descontrolados de Barracas.

Ricardo Talento, revive así los inicios del grupo:

"Éramos seis personas, durante la "nochevieja”.., acá, actuando junto con los vecinos.

Decidimos trabajar con los vecinos porque creemos que es una forma muy genuina de hacer teatro, creo que es la esencia del teatro; es la comunidad expresándose y comunicándose a través del teatro, ; es una de las cosas genuinas del teatro!

Entonces empezamos a trabajar y... ¿qué hicimos con los vecinos? empezamos a trasmitirle lo que nosotros sabíamos: actuar, cantar, hacer una manifestación que es muy autentica de acá de Buenos Aires, que se llama "murga”, comenzamos a tocar instrumentos..., bueno, transmitíamos lo que sabíamos a los vecinos y con eso, empezamos a armar espectáculos.

¿Y en qué consisten los espectáculos?... En armar nuestras historias, qué cosas nos van pasando, qué cosas nos pasaron con el tema de la crisis, es decir, el quebramiento de valores, el quebramiento como personas, la locura social que nos ha producido.., porque aunque nos hacemos los desentendidos .... iestamos muy locos! $!^{93}$ "

Estas agrupaciones conforman un polo cultural muy poderoso en la zona sur de la Capital, ya que además de la fuerza de su impronta, involucran a 600 vecinos, y sus directores, ejercen una labor esencial como difusores e introductores de esta modalidad de teatro entre nuevos colectivos, constituyendo un fenómeno particular de producción teatral con rasgos característicos, que señalan su auténtica y distintiva identidad.

Cristina Paravano, nos refiere como surgió la colaboración entre ambos grupos:

"Claro, ellos empezaron a trabajar a partir de nosotros, ellos eran antiguos teatreros., pero en lo que es teatro comunitario les entusiasmó nuestra propuesta, y hacen años que están trabajando... bueno, nosotros trabajamos juntos con ellos, y sobre todo, Adhemar Bianchi nuestro director, y Ricardo Talento el director de los Calandracas, trabajan juntos y están llevando adelante esta propuesta de multiplicar el teatro comunitario; de hecho ha habido resultados estupendos, en este momento a raíz de la necesidad de la gente de juntarse y de juntarse en algo que les una y que los una por el placer y el gusto de contar su propia historia, por la música, el canto, el teatro, en fin por todo eso, hace que en este momento, haya 18 grupos funcionando" 94 .

Y esta colaboración ya viene de lejos, hasta el punto que el último de los grandes montajes del Grupo Catalinas Sur "El Fulgor Argentino Club Social y Deportivo", es una codirección entre ambos autores y una obra, cuyo impacto sirvió, como dijimos, para animar a otros colectivos a intentar esta apuesta por el teatro comunitario.

92 El objetivo de este tipo de teatro consiste en poner en juego la creatividad y el intercambio de opiniones, para la búsqueda de acuerdos conjuntos para lograr cambios. En el teatro foro se escenifican temas sociales y se utiliza el teatro como herramienta para incidir en el tejido social., siguiendo las pautas de Boal ,en su Poética del Oprimido, de convertir al espectador en sujeto protagónico; se le habilita para ensayar formas teatrales por etapas, pasando de ser testigo, a protagonista.

93 Ibídem: Entrevista a Ricardo Talento director del grupo Los Calandracas y del Circulo Cultural Barracas el 3 de julio de 2004, en Buenos Aires.

94 Ibídem: Cristina Paravano, actriz-vecina del Grupo Catalinas y su responsable de divulgación por correo electrónico, nacida en Capital Federal, el 18 de octubre de 1947.Entrevista realizada por mí el 16 de agosto de 2004, en los camerinos del Galpón de Catalinas, en Buenos Aires. 
A través de las entrevistas a los dos directores más emblemáticos (Bianchi y Talento) junto con las de otros grupos que se han iniciado con posterioridad a 2001 (Res o no Res, Mate Murga, Patricios Unidos de Pie, Alma Mater de Flores, Pompeya, Boedo Antiguo, Floresta, etc.) intentaremos acercarnos a la idiosincrasia del teatro comunitario, una interesante apuesta por la reconstrucción de la solidaridad social y cultural, en la Argentina de la crisis.

Ricardo Talento ${ }^{95}$, director del Centro Cultural Barracas nos dice:

"No es casual que estos proyectos nacieran en los barrios del Sur, que son los barrios más postergados y han conservado su identidad. No sólo La Boca y Barracas, sino también Mataderos, Parque Patricios, Pompeya.

Otra cosa que también tiene que ver, es la actitud con la que uno pone un teatro o hace teatro. Porque en definitiva son los vecinos los que están haciendo teatro, entonces ya tenés una integración barrial. A mi todo el mundo me reconoce como el director del grupo del barrio. No es que uno se instala como un paracaidista porque consiguió un local, entonces estoy en Barracas. Es una actitud hacia el barrio, es una cuestión de actitud. Si hay cien, trabajamos con cien y hay que buscar lugar para todos, esa es nuestra filosofía, aquí no hay exclusión sino integración. Todos tienen que tener un lugar y eso también se transmite hacia afuera. Este teatro está integrado a la comunidad, y tiene que tener conexión con esta comunidad.

A nuestros grupos vienen actores profesionales, pero llegan en calidad de vecinos, como el caso de Sergio Ponce que trabajó mucho tiempo con nosotros; es actor profesional, titiritero, pero viene en calidad de vecino.

En un momento nos tuvimos que plantear este tema, porque si aceptamos al plomero en su calidad de vecino, ¿porque no vamos a aceptar al actor en su calidad de vecino?, de lo contrario estamos excluyendo al actor y se nos produce una contradicción. El actor no viene en calidad de mostrar que él es el que sabe, como los demás viene y participa como cualquier otro vecino"

La singularidad de la propuesta reside en que, a diferencia de lo que sucede con otras prácticas del teatro popular, que muchas veces se definen como tales por su temática, aquí los ejecutantes, los artistas, son los propios vecinos.

Esta orientación implica un enfoque muy distinto al que requiere otro tipo de teatro. En primer lugar, porque el concepto que gravita todo el tiempo es el de relato épico, es decir, lo que se cuenta son los temas de los hombres y no del hombre singular en términos psicológicos e individuales; y en segundo término, porque, siempre se trabaja con una gran cantidad de personas, (ninguna es imprescindible como individualidad, pero todas son necesarias para la totalidad).

Adhemar Bianchi director de Catalinas, nos lo expone de la siguiente manera:

“construir con los vecinos es muy rico en lo artístico, en cómo se van dando las pinceladas. Por este camino aparecen hechos absolutamente sorpresivos. A veces el profesionalismo hace que la mirada esté demasiado estructurada. Cuando uno se mueve entre vecinos, le disparan de todos lados, lo cual da mucha energía al trabajo ${ }^{96 "}$.

Sobre esta base, Adhemar Bianchi considera que, además de la riqueza de trabajar con vecinos "no profesionales" (con grandes deseos de producir), le interesa aprovechar la potencialidad

\footnotetext{
95 Entrevista a Ricardo Talento, director del Teatro Cultural Barracas y difusor junto con Adhemar Bianchi del teatro comunitario. Entrevista realizada por mí, en el Círculo Cultural Barracas, el 3 de julio de 2004.

96 Adhemar Bianchi, nacido en Montevideo en 1945 director de Catalinas Sur, primera entrevista realizada por mí el 17 de agosto de 2003 en el escenario del Galpón de Catalinas Sur, del Barrio de La Boca. Buenos Aires.
} 
de los recursos humanos con los que cuenta. Su método es trabajar con el concepto definido por él mismo de: "cuál es su gracia".

A partir del bagaje de lo que cada integrante trae consigo, el Grupo se ocupa de aprovecharlo dramáticamente. El teatro comunitario ha aglutinado especialmente a los sectores sociales medios, que son quienes se han integrado mayoritariamente en este tipo de propuestas culturales, ya que los sectores sociales inferiores, más afectados por el desempleo, la indigencia, los problemas de integración social, menor disponibilidad de tiempo libre, (déficit que disminuye a medida que se asciende en la estructura social) y tienen otras prioridades entre las cuales las actividades culturales o deportivas, no son las preferentes ${ }^{97}$.

De ahí que el teatro, como opción cultural, sea una actividad que atraiga sustancialmente a las capas medias de la población. Ricardo Talento nos lo explica:

"Este sector es el más quebrado hoy, en nuestro país. Somos sector medio, no estamos disfrazados de nada. Somos lo que somos y trabajamos con el sector que somos, porque tenemos una necesidad terrible, es el sector más quebrado. Es un sector que forma opinión, pero que a veces no tiene en claro para donde van las cosas; un día inclina la balanza por Blumberg y al otro, para el otro lado, está muy bombardeado, nunca sabe para donde va, y además es un sector que tiene totalmente trastocado los valores. Es muy importante trabajar con los sectores medios.

En Brasil, estuve hablando con el Rector de la Facultad de Río de Janeiro y le llamó la atención nuestro trabajo con la clase media, porque allá todo el mundo trabaja con los sectores más pobres.

Los sectores medios que forman opinión son la bisagra; son los que todavía tienen recursos, no sólo culturales, e influyen en esta religazón social que hace falta. Uno no se está disfrazando de nada, trabajamos en el lugar de donde somos y con los vecinos. No vamos a la villa a trabajar y luego volvemos a casa confortables y bien comidos. No. Trabajamos con lo que somos, con la gente, con nuestra gente, y eso, creo que es muy importante. Se liga también con lo que hablábamos en relación a la responsabilidad del artista, en cuanto que, el artista se cree que debe llevar algo que él posee a los desposeídos, cuando por ahí en sí mismo él es un desposeído, y no lo puede ver.

La cultura de mercado ha entrado tan profundamente en los sectores medios, que es una de las cosas que uno trabaja continuamente. Hay gente que participa de este proyecto, pero lo está evaluando con cultura de mercado, pensando ¿qué gano yo con esto?, ¿que saco, que pongo?. Todo el mundo que manifieste voluntad de estar en el proyecto, está incluido; ahora bien, estamos todos incluidos, pero se preguntan cuál es la diferencia, porque en el fondo en el casting te eligen, entonces sos el elegido, pero en ésto, cuando le decís que está incluido quiere saber cual es su premio. El premio es su evolución, si participas vas a crecer como ser humano y ese es el premio, no que alguien te venga a decir, fuiste el mejor entre diez. Son cosas que cuesta mucho verlas, terrible ${ }^{98,}$

En épocas de tan acentuadas e injustas diferencias socioeconómicas y, en medio de una crisis de mundo que cambia los valores por efectos, estos teatristas proponen la utilización del

97 SALVIA, Agustín, TAMI, Felipe (coord): Informe sobre la Deuda Social Argentina $n^{\circ} 1$, Las grandes desigualdades UCA, Buenos Aires, año 2004, pág. 169. Según dicho informe los sectores sociales más vulnerables, priorizan su tiempo libre en mayor medida a estar con la familia, la pareja o los amigos. La segunda actividad mencionada, se refiere a actividades pasivas como mirar televisión, escuchar radio o música; y la tercera, al descanso. En la clase media, la mayoría dedica su tiempo libre al descanso; luego a las actividades culturales y las relaciones interpersonales y, en tercer lugar, a escuchar música, radio o mirar televisión.0

98 Ibídem: Entrevista a Ricardo Talento, realizada por mí, en el Círculo Cultural Barracas, el 3 de julio de 2004. Sobre la composición social de su propio grupo nos dice: "Clase media baja..,hay chicos jóvenes o gente grande desocupada o subocupada; hay muy pocos, deben ser contados los que están haciendo el trabajo que querían. Acá hay gente que era metalúrgica y ahora hace changas (chapuzas)hay una gran cantidad de desocupados; hay algunos docentes, creo que los que mejor han sobrevivido son los docentes, porque al menos se prepararon para eso, trabajan en eso, y tienen algo fijo". 
teatro, como herramienta o instrumento de conocimiento y comunicación, para lograr así reconstruir, una identidad social y cultural fragmentada.

Como fenómeno que no nació organizado por instituciones, sindicatos o partidos políticos, si no a partir de una circunstancia claramente palpable, la exclusión cultural, -en la que sistemáticamente van agrupándose más y más individuos-, los teatristas encuentran en su teatro las armas, para erigirse como bastión de resistencia.

En tiempos de desazones, angustias, indolencia generalizada y emigraciones desesperadas, los grupos, Barracas y Catalinas, logran crear varios espectáculos simultáneamente, porque el teatro es resistencia y también resilencia o capacidad de construir frente a la adversidad ${ }^{99}$. La expansión del teatro comunitario está en relación directa con el desarrollo de la crisis argentina, de hecho el quiebre que representa diciembre de 2001, significó el impulso definitivo a ésta modalidad teatral que pasó de dos grupos consolidados, a veinticinco, porque cómo nos dice Ricardo Talento:

Adhemar Bianchi nos dice al respecto:

"Yo diría que todo momento de bisagra, de detonante social, implica reacomodación; en ésta nueva reacomodación mucha gente buscó canales de participación y trató de unirse, de estar juntos, o sea, resistir ante una situación realmente terrible. Fue resistir tratando de fortificar la red social, y el teatro es un gran fortificador de organizaciones y redes sociales cuando se hace con un planteo comunitario, digamos con un enclave regional, barrial, social ${ }^{101}$ ",

Pero ante todo son los representantes de los nuevos grupos teatrales, los que confirman la relación directa entre la agudización de la crisis -tras los sucesos de 2001-, y la puesta en marcha de los nuevos proyectos:

Virginia Pereyra ${ }^{102}$ informante del Grupo de Teatro Comunitario Alma Mate de Flores nos dice:

"La historia de Argentina, es una historia de crisis recurrentes. Podría llegar a decirse que dentro de esta crisis prolongada, los sucesos de diciembre de 2001 funcionaron como emergente, donde salieron a luz los problemas que se venían arrastrando desde mucho tiempo atrás. Visto esto como un proceso, a la par encontramos el teatro comunitario. Ya en la década de los 80, comenzó un fenómeno de captación de los espacios públicos y de cultura por parte de la población, donde paulatinamente, la gente empezó a perder el miedo provocado por la dictadura militar. Éste fenómeno, se aceleró en los últimos años de la década del 90 por diversos motivos. La plaza en la que actuamos, la Plaza de los Periodistas, tiene historia de vaivenes múltiples: fue un convento, fue un baldio, hubo un circo, quisieron hacer un shopping, y la lucha vecinal logró torcer éste último objetivo mientras el país se convertía en un gran shopping. Los vecinos triunfaron, y 4 años después surge un grupo de teatro que lleva a escena esa lucha. Nuestro teatro no aspira a ofrecer soluciones concretas a la crisis argentina. Como Unamuno, podemos decir. "¿ha de hablarse tan sólo en vista del porvenir inmediato, el fruto que nuestro oyentes saquen de lo que decimos?” Nosotros sabemos que el espíritu produce espíritu, como la letra, letra, y la carne, carne. Si el pueblo no entiende, siente empero, comezón de entender. A partir de nuestra comezón, hacemos teatro que genera comezón en los demás que nos ven.

99 Término que se aplica para catalogar esta modalidad de teatro DUBATTI, Jorge: El teatro laberinto. Ensayos sobre teatro argentino. Ed. Atuel, Buenos Aires, 1999, p. 9-24

100 Ibídem: Entrevista a Ricardo Talento, director del Teatro Cultural Barracas y difusor junto con Adhemar Bianchi del teatro comunitario. Entrevista realizada por mí , en el Círculo Cultural Barracas, el 3 de julio de 2004.

101 Adhemar Bianchi, director de Catalinas Sur, segunda entrevista realizada por mí el 15de agosto de 2004 en el Galpón de Catalinas Sur, del Barrio de La Boca. Buenos Aires.

102 Entrevista realizada por mí a Virginia Pereyra, el 3 de julio de 2004, en una cafetería de la Plaza de los Periodistas, de Buenos Aires. 
Desde diciembre de 2001 se hizo presente la necesidad de salir de nuestras casas y ponernos en contacto con los demás. Ya sea para defender nuestros derechos, ya sea también por una cuestión de identidad, de pertenecer a un barrio, conocer su historia, compartir con el vecino un proyecto común; todo eso genera infinidad de cosas que arrastran a los demás, y es por eso que en 2 años el grupo se duplicó en cantidad de gente. A la vez, también aumentó la creación de otros grupos en distintos barrios con los cuales se está en contacto, tanto por reuniones entre los distintos directores, como por festivales y eventos en donde todos asistimos".

Por su parte Edith Scher ${ }^{103}$ directora del Grupo de Teatro Comunitario Mate Murga nos comenta:

"Creo que la motivación más que nada, actúa como una construcción colectiva que contradice el paradigma hegemónico del: "sálvese quien pueda". Por un lado ha unido al grupo. Por otro lado, considero que la crisis se mete en el pensamiento de las personas, en su accionar y se filtra, creando en algunas ocasiones, conductas individualistas que tratamos de combatir, apostando al trabajo en conjunto y a la discusión de los conflictos"

El Grupo de Teatro Comunitario de Pompeya a través de María Florencia Calvosa Martín ${ }^{104}$, encargada de prensa de dicho grupo nos comenta:

"Creo que a partir de la crisis este grupo se conformó, y a partir de conformarse y de que cada integrante cuente con un espacio y un grupo de pertenencia, el grupo se consolidó. La idea del grupo, trata de recrear y rescatar la historia, la memoria y la identidad del barrio de Pompeya"

La esencia del teatro comunitario tiene como fundamento el arte y la transformación social, porque si bien, continuamente se le reconoce al ser humano su potencialidad creadora, por otro lado, es una de las cosas que más se mutilan relegando la creación exclusivamente para los artistas, mientras el resto no tiene posibilidad de crear.

El proyecto del teatro comunitario parte del supuesto contrario: todos somos creadores; por lo tanto, podemos actuar y comunicarnos a través del teatro. En definitiva, permite a la persona ser protagonista del hecho artístico y establecer a través de él un vínculo con sus pares, teniendo un lugar de pertenencia en el barrio. Ricardo Talento nos dice:

"Volver a jugar, que es otra de las cosas mutiladas. El ser humano pasó los 12 o 13 años y ya no juega más; y el no jugar es una mutilación muy grande, perdés la capacidad de crear, de inventar, de imaginar otras formas. También está la otra cosa, que es tratar al arte como si fuera la frutilla de la torta, lo exquisito, lo superfluo. En el Foro de Porto Alegre, surgió una cosa muy linda: se estableció que el arte es un derecho. Así como la educación, la salud, el pan, el arte también está entre las prioridades del ser humano. Si somos capaces de imaginar otra forma, quizás imaginemos otro mundo posible y dejemos de creer que ésta, es la única forma.

(...)En cuanto a la responsabilidad del artista, todavía se tiene el concepto de que el artista tiene que ir al barrio o a los sectores pobres, a mostrar su arte, y nosotros pensamos que la responsabilidad del artista es sociabilizar sus saberes, para que el otro pueda desarrollar su capacidad creativa y empiece a imaginarse de otra manera.

103 Entrevista realizada por mí, el día 7 de agosto de 2004, a Edith Scher directora del grupo Mate murga, en el Círculo Cultural Barracas en Buenos Aires, donde ensaya en ocasiones el grupo.

104 Ibídem: Entrevista realizada por mí, el día 4 de agosto de 2004,a María Florencia Calvosa Martín , responsable de prensa del grupo de teatro comunitario de Pompeya, en el Centro Cultural Homero Manzi de Buenos Aires. 
Un chico de la villa en este momento puede imaginarse tocar un tambor, puede imaginarse armar un grupo de música, por ahí no puede imaginarse un estudio secundario o universitario; pero a partir de que armó la banda de música, o a partir que tocó el tambor o a partir que hizo teatro, se empieza a imaginar que también puede ir a la universidad, puede imaginar que él es capaz de decidir qué hacer con su vida. Ese es el paso, no se va a convertir nada más que en músico, eso le abrió el camino, el panorama. Volvemos a lo mismo, descubrió que es un ser creativo y ya no acepta las cosas como son, empieza a decir: "esto podría ser de otra forma". Por eso creo que se mutila, y una de las partes más peligrosas del ser, su individualidad, solo crece con el otro, crece en lo colectivo y lo colectivo, se enriquece con su individualidad.

Esta cultura individualista que tenemos, de creer que en lo colectivo perdemos, es una actitud individual: aprendo o estudio tal cosa, pero me lo quedo para mí. Pero cuando se descubre que junto con lo colectivo, crece la persona y crece lo colectivo, que ambos a su vez se realimentan continuamente, es también una... iApertura maravillosa!, pero cuesta, cuesta mucho descubrir eso.

Ésta cosa del teatro no es una herramienta para uno, es en sí mismo un proceso de enriquecimiento y de educación. Son muchos parámetros que tenemos impuestos, que debemos empezar no a romperlos, pero sí a cuestionarlos ${ }^{105}$ "

El teatro comunitario requiere una cuidadosa elaboración que asocia, una necesidad social con una propuesta estética, ya que además de poner siempre bajo la lupa temas vinculados a la historia argentina (la injusticia, la identidad y la memoria), recupera géneros populares como el sainete, la murga o el circo, los revaloriza y combina, es decir, se apropia de ellos desde nuestro tiempo.

La elección de esta línea de trabajo da como resultado un punto de vista paródico, (todos estos géneros van de la mano del humor), que nunca pierde de vista aquello de mirar el mundo desde el barrio.

"Para mí el teatro popular, es aquel que está hecho por los vecinos para los vecinos. Creo en el teatro como herramienta de comunicación, como fiesta, como un modo de participar y conservar la memoria. Muchos fenómenos históricos probablemente lleguen más a la gente a partir de clásicos como Shakespeare, que de los libros de historia ${ }^{106 ”,}$ sostiene Bianchi.

Defender la alegría, como un atributo especialmente necesario en las circunstancias que atraviesa el país, se postula como una premisa de todas las obras de teatro comunitario; reivindicar la alegría como una necesidad en este tipo de montajes, aún pasando por temas dolorosos, como cuando el Fulgor Argentino hace repaso de los últimos acontecimientos y lo hace a ritmo de murga, desdramatizando los hechos que todavía duelen al público allí presente, como nos dice Ricardo Talento:

"Si perdemos la risa y la alegría, estamos derrotados. Lo más hermoso que tiene el ser humano es la capacidad de imaginar. No casualmente esa capacidad, que es peligrosa porque escapa a todo tipo de control, es la que intentan coartar continuamente”

Así se fue consolidando este fenómeno de unir la protesta con el arte, para Ricardo Talento:

"Hace poco un espectador me dijo que Los Calandraca hace años que estamos "caceroleando". Para mí fue un elogio. El vecino, es protagonista del hecho cultural, no es exclusivamente receptor de lo que expresa otro artista. Esta esencia es similar a las de las asambleas: recuperar el

105 Ibídem: Entrevista realizada por mí al director de teatro Ricardo Talento en el Centro Cultural Barracas, Buenos Aires, el 3 de julio de 2004

106 Ibídem: Entrevista realizada por mí a Adhemar Bianchi en el Galpón de Catalinas Sur, Buenos Aires, el 17 de agosto de 2003. 
protagonismo, el hacer frente a la mala representación de la clase política. Por eso las asambleas tienen ésta teatralidad. Una forma de comunicar que me estafaron, es acostarme en la puerta del banco y rebelarme contra esa situación. Nos están llamando a Adhemar y a mí, como referentes del teatro comunitario porque los vecinos de Mataderos y de Flores se preguntan cómo seguir avanzando en sus comisiones de cultura. Yo como vecino, me puedo comunicar cantando, bailando o actuando. ¿Se imaginan lo que sería Buenos Aires con 10 grupos de teatro comunitario surgidos con las características del grupo Catalinas y Los Calandracas, que no imitamos formas de teatro dominante, sino que generamos nuestros propios lenguajes? ${ }^{107}$,"

Probablemente esta profunda convicción sea la que ha llevado tan lejos este modo de entender la relación entre la vida y el arte. Hoy, después de muchos años de trabajo, el teatro comunitario hace crecer sus raíces en muchos barrios de la Capital, el Gran Buenos Aires y el interior del país.

Podemos distinguir una serie de características que configuran este tipo de modalidad teatral:

1. Es una apuesta contra la desterritorialización que promueven las nuevas redes de comunicación: televisión, internet, conexiones satelitales, chateo. El teatro exige territorialidad: la reunión en un espacio geográfico real. A través de una comunicación directa y sencilla, los espectáculos logran el milagro de la comunión intensa con ese público. Una reunión basada en el intercambio humano directo de presencias. Una práctica de cuerpos presentes, ahora que todo tiende cada vez con más insistencia, a lo virtual. Adhemar Bianchi lo entiende así:

"Yo creo que es una confluencia, el teatro es una forma de comunicación entre los hombres, antes que nada requiere que alguien actúe y alguien lo mire, después podés agregarle lo que quieras. El 75,80\% de nuestro público no va al teatro, y viene al Catalinas.. En un documento dijimos, que el vecino del $4^{\circ} \mathrm{B}$ al ver que el vecino del $3^{\circ} \mathrm{A}$, está haciendo Shakespeare en la plaza, se dice.,¿jpor qué yo no puedo...? Hay una empatía, una simpatía de la gente por ver a sus iguales, y me parece importante destacarlo. Por otro lado, nuestras temáticas siempre tienen que ver con lo social, con el rescate de las técnicas populares, y su utilización más o menos adecuada, contribuyó a la recomendación "boca a boca", porque las críticas sirven para el núcleo que las lee"

2. Es una postura contra la homogeneización cultural de la globalización. A diferencia de otras formas artísticas, complementarias con los procesos de globalización, el teatro favorece la singularidad de las identidades culturales, el regreso al saber del grupo, la región o la nación.

Enrique Papatino director del Grupo de Teatro Comunitario de Matadero dice:

"Somos parte de Res o no Res algo más de 50 vecinos-actores del barrio, que en estos dos años logramos crear un trabajo colectivo, en equipo, donde cada uno aportó, desde sus habilidades, a ésta propuesta teatral; primero nos acercamos, después nos animamos y ahora... ii iactuamos!!!

Decidimos contar nuestra historia, hablar de nosotros, de nuestro lugar a través del teatro y de la música ${ }^{108 "}$

107 Ibídem: Entrevista realizada por mí al director de teatro Ricardo Talento en el Centro Cultural Barracas, Buenos Aires, el 3 de julio de 2004.

108 Grupo de teatro comunitario de Mataderos "Res o no Res". El punto de partida de este grupo se inició con "Desde el Alma", pero su apuesta más consolidada la constituye "Perfume Nacional, la Patria dejará de ser colonia" bajo la dirección de Enrique Papatino, creación colectiva que pone de manifiesto el profundo significado que tuvo y tiene para los vecinos, la instalación del matadero y la llegada de los frigoríficos, hechos que consolidaron en el barrio un sentimiento de identificación y pertenencia. Este espectáculo, con más de 50 vecinos- actores en escena, consta de cuatro actos, en el que se retratan, a través del lenguaje musical y a veces del humor, algunos pasajes imperdibles de la dura historia del país. El disparador de la obra está íntimamente ligado, a la política de penetración británica en el Río 
3. Es una forma de actuar contra la insignificancia, el olvido y la trivialidad. El teatro se plantea como espacio de proyección de la memoria, como oasis de sentido, en una realidad que parece haber perdido su principio de organización. A través de sus metáforas invita a repensar la historia del país, y a elaborar un discurso de la memoria. Adhemar Bianchi aclara:

"Obviamente que nosotros cuando hablamos de identidad, hablamos de memoria; pero también hablamos de presente, hablamos de problemáticas..., y cuando hablamos de la memoria no hablamos de la añoranza, hablamos de la memoria para darnos cuenta de determinadas cosas que siempre suceden; entonces nosotros no colonizamos, aconsejamos la memoria porque eso une, pero los barrios después van trabajando de acuerdo a muchas problemáticas. Considerando que hay mucha gente que de por sí, no trabaja con la memoria sino directamente con la problemática de su barrio"

"La memoria barrial está atravesada siempre por la historia del país. No se podría contar la vida en Mataderos, sin mencionar los frigorificos. Y si se habla de la carne, posiblemente se esté aludiendo a los ingleses y a la relación imperio-colonia. Desde las pequeñas historias, se llega a las grandes. Creemos que la memoria es un elemento fundamental de identidad. Pero no sólo la memoria histórica de los momentos fundamentales del devenir de la Argentina, sino también la de las familias y los barrios. En el lugar propio se encuentran muchas claves ${ }^{109 " .}$

En la mayoría de los casos, las historias que se cuentan tienen que ver con el lugar de origen. Cada integrante recoge testimonios de sus familiares y allegados, y con el aporte colectivo, condensado en la mirada del director, se crea el texto; así nos dice Adhemar Bianchi:

"Diría, que es un rescate de cosas que están en nuestra cultura, en nuestra memoria teatral; nuestras formas responden a lo que podría ser el sainete, la zarzuela, la opereta, los títeres, a lo que son las viejas corrientes de nuestro teatro. Conceptualmente, nuestra problemática no tiene que ver con un drama psicológico, ni con un personaje; esa confluencia, de técnicas populares y temáticas sociales, es lo que le ha dado repercusión a nuestro teatro ${ }^{110 "}$

4. Es una actitud contra la hegemonía del capitalismo autoritario y el neoliberalismo. El teatro se configura en la sociedad actual como un típico instrumento de contrapoder, de creación de espacios alternativos para la construcción y el desarrollo de otras subjetividades ${ }^{111}$, que se transforman en armas contra el individualismo y el narcisismo introspectivo, que favorecen la relación social, el trabajo en equipo, y la práctica comunitaria, grupal. "No se va al teatro para estar solo". El teatro es resistencia, contra las nuevas condiciones culturales que impone el neoliberalismo.

Virginia Pereyra ${ }^{112}$, vecina-actriz del Grupo de Teatro Comunitario Alma Mate del barrio porteño de Flores, nos expone como surgió y las características de su grupo:

"Los directores de Alma Mate de Flores son Ana Laura Kleiner y Alejandro Schaab, y surgió la idea a partir de una reunión en julio de 2002 anunciada de boca en boca por el barrio; se

de la Plata. Entrevista realizada por mí a Enrique Papatino, en la Plaza de los Dos Congresos en Buenos Aires, tras la actuación del Grupo Res o no Res, el 3 de diciembre de 2004.

109 Ibídem: Entrevista realizada por mí a Adhemar Bianchi, en el Galpón de Catalinas Sur, el 17 de agosto de 2003.

110 Ibídem: Entrevista realizada por mí a Adhermar Bianchi, el 17 de agosto de 2003, en el Galpón de Catalinas Sur, en Buenos Aires.

111 PAVLOVSKY Eduardo: La voz del cuerpo, Ed. Astralib Cooperativa Editora, Buenos Aires, Argentina, 2004, pp. 119-121.

112 Ibídem: Entrevista realizada por mí a Virginia Pereyra el 3 de julio de 2004, en una cafetería de la Plaza de los Periodistas de Buenos Aires. 
juntaron 35 personas en una pequeña sala teatral, convocadas por Ana Laura Kleiner que, ante una realidad que dolía y desolaba, decidió convocarnos y jugarse por ésta aventura común. Arte y esperanza, para nosotros y para la gente de nuestro barrio. A la semana siguiente, Adhemar Bianchi del grupo Catalinas y Ricardo Talento del Teatral de Barracas, estaban con nosotros en la reunión que dio origen al grupo. En esa charla, nos brindaron toda su experiencia (...), surgieron temas que fueron fundamentales a la hora de poder concretar éste sueño que se estaba gestando, cómo: la autogestión del grupo, el lugar físico donde llevaríamos adelante la actividad, cómo difundirla, qué queríamos contar, a quienes estaba dirigida, entre otros tantos que surgieron después. Decidimos un monto de \$3 (U\$ 1 aprox.) por persona y por mes, como aporte al grupo, para afrontar los primeros gastos, cifra que mantenemos en la actualidad, ya que junto a lo recaudado en concepto de gorra en las actuaciones en la plaza, son los únicos ingresos con los que contamos.

Ensayamos los sábados de 15:30 a 19:30. Ahora somos 37 personas, hay integrantes desde 3 años hasta 80 años, que se dedican a actividades muy variadas y como contamos con gente de todas las edades, hay varios que son estudiantes; también hay gran cantidad de docentes, hay empleados, y profesionales sobre todo provenientes del área de Humanidades. Nuestro lugar propio, es la plaza. Alli ensayamos, porque es la mejor manera de mostrar lo que hacemos y de estar abiertos a los vecinos que quieran participar. En una de nuestras letras decimos: "La plaza no tiene puertas y siempre podes entrar”, esa es la idea. No obstante, si el tiempo no nos ayuda, tenemos nuestro lugar en la Sociedad de Fomento. El grupo cuenta con 2 años de edad. A lo largo de éstos años, hemos estrenado "Promesas Rotas", la cual seguimos presentando, y estamos preparando otra obra para fin de año. Nuestra obra está preparada para ser montada sin equipo de sonido o luces, sin escenografía y por lo tanto podemos presentarla en cualquier lugar. Actuamos en nuestra plaza, pero hemos sido invitados a otras plazas, escuelas, lugares carenciados, inclusive, hasta a una maternidad; también hemos participados de festivales junto a otros grupos comunitarios"

5. Es una actitud contra la pérdida de la praxis social. El teatro se sale de sí y parte nuevamente en busca de su perdida función social, desde una nueva experiencia y desde nuevos saberes. Este tipo de teatro no sólo ayuda a cambiar la conciencia del espectador, sino que, al servicio de las necesidades de la comunidad, contribuye a cambiar la realidad.

Así en su despedida "El Fulgor Argentino", cuando canta "A barajar y dar de nuevo" dicen:

"Son nuestras voces que entonan la retirada/ son nuestras voces que no callarán jamás/. Cantando siempre por nuestra historial por la memoria, la dignidad. (...)Porque hoy nos quieren convencer de la derrota/ Porque hoy nos quieren inculcar la soledad/ Nuestra utopía está presente,/ sumando gente, de aquí y de allál13"

Por su parte, "Los Descontrolados de Barracas" necesitan hacerse oír y pedir justicia. El pueblo murga o la murga pueblo, necesita la purga catártica para qué con la identificación del problema, se tome conciencia, se reflexione y se actúe en consecuencia. No obstante, las letras encierran, a pesar de tan desolado panorama, una actitud esperanzadora: "Nos pudrimos de tanto corral, esto se tiene que acabar"... "que devuelvan la guita y las ilusiones, porque la murga ya se cansó de tantos mafiosos. Salió a la calle y dijo:¡ Basta de acorralar!".

Ácida pero verdadera, la murga propone enfrentar la realidad y no negarla. Sin conceder ni ceder, los murgueros se encargan de revisar el presente en cada representación, a partir del

113 Programa de mano de la función de El Fulgor Argentino Club Social y Deportivo, 1930-2030. Creación colectiva. Dirección Adhemar Bianchi y Ricardo Talento. 
reconocimiento de que: "la calle nos ha juntado con todos nuestros vecinos", y con la esperanza de que a partir de esta particular forma de resistencia se genere algún cambio ${ }^{114}$.

6. Es una postura contra la parálisis que genera la pauperización. Dijimos que el teatro actual no sólo es resistencia, también resiliencia, capacidad de construir en tiempos de adversidad. En este sentido el teatro resiste contra la pauperización y el avance del empobrecimiento. Frente a los avances tecnológicos -en gran parte inaccesibles por sus costos, promueve la actitud resiliente del regreso a la convivencia. La adversidad de los tiempos exige estas mutaciones, y redefine la resistencia y la resiliencia como expresiones de lo nuevo ${ }^{115}$. Ricardo Talento hablándonos de la obra Zurcido a mano nos dice:

"Es muy fuerte., por ejemplo en éste espectáculo, exponemos la locura que han producido muchas cosas, que sé yo., un ejemplo, acá a dos cuadras, una autopista tiró mitad de un barrio abajo: ;30.000 personas se fueron del barrio en la época del Proceso, de la Dictadura! Te ibas o te ibas, o si no te tiraban la casa abajo, no había vuelta.

Eso produjo locuras, suicidios..., todo tipo de locuras, y un barrio destruido, un barrio dividido en dos: a un lado de la autopista está toda la gente de clase media, y al otro lado, todo totalmente abandonado, total pobreza, la historia de "los desbarrancados", como decimos nosotros; y así como las familias, la clase media también se ha ido cayendo. Fueron perdiendo el trabajo. Por ejemplo, el tema de los cartoneros (los habrás visto acá) la gente juntando basura y la gente; comiendo de la basura.!., bueno todo eso por suerte, lo podemos manifestar en teatro, hacemos una catarsis representándolo y comunicándolo a otros vecinos, y los otros vecinos como espectadores, también harán su catarsis; y a tal punto, que desde hace dos años a ésta parte, en la ciudad de Buenos Aires se han armado ¡16 grupos de teatro de vecinos!..., vecinos que cuentan sus historias a través del teatro.

Todo mas allá de la cuestión artística; es no quedarse solo, es organizarse, es juntarse con otros, es empezar a desarrollar nuevamente desde lo colectivo, que es como funciona el ser humano,j desde lo colectivo!

Porque esa fantasía primermundista que nos impusieron y que nos creímos (que esto era primer mundo), nos llevó a que cada uno estuviera en su casa, con su video, y su tarjeta de plástico, aislado en la computadora...

Bueno todo eso se derrumbó, y entonces nos dimos cuenta de que existían más cosas y nos empezamos a mirar; empezamos a juntarnos y creo que el arte es una cosa genuina, porque es algo inherente al hombre; porque acá sostenemos que todo el mundo puede manifestarse desde lo artístico y todo el mundo puede imaginar, puede cantar.., vos fíjate que acá viste gente cantando, viste a tipos que hace dos años no cantaban, que no los habían dejado cantar nunca porque decían que sólo cantan los especialistas., o que se le decía, vos sos “ sordo ” y no podés cantar... Entonces desarrollar eso, es potencializarse desde lo individual y desde lo colectivo; yo en lo colectivo me puedo manifestar, puedo cantar, puedo actuar, puedo volver a imaginar, cosa que hemos dejado de hacer y no sólo acá en la Argentina, creo que en el mundo entero.

$Y$ eso es un gran potencial que hemos estado perdiendo, o que nos han hecho perder, dado que nos dan todo digerido como para que no pensemos...

No pensemos, no imaginemos.., y si no podemos imaginar, ¿cómo vamos a soñar un mundo mejor? , ¿cómo podemos lograr una comunidad mejor, si no somos capaces de imaginarla siquiera ?”

114 Ibídem: BIDEGAIN, Marcela: "Los Calandracas, una vocación comunitaria” en DUBATTI, Jorge (coord.): El teatro de grupos, compañías y otras formaciones (1983-2002). Micropoéticas II. Ed. Centro Cultural de la Cooperación, Buenos Aires, 2003, pág. 308.

115 DUBATTI, Jorge (coord): El nuevo teatro argentino de la postdictadura. Micropoéticas I, Centro Cultural de la Cooperación, Buenos Aires, 2002, p. 50. 
Tras un largo período de difusión boca a boca, el éxito de El fulgor argentino, le dio un relevante empujón a la propuesta del teatro comunitario en general, coincidiendo con la agudización de la crisis. Como no atesoran sus conocimientos, sino que los comparten con gran generosidad, los grupos pasan su experiencia, producen arte y enseñan cómo transmitirlo. Abren sus puertas para ser vistos y para compartir su saber.

Y como afortunadamente estos fenómenos se propagan muy rápidamente, es bueno señalar que en este momento, agrupaciones similares ya se han conformado en la provincia de Buenos Aires, en otras provincias y en numerosos barrios porteños.

\section{La expansión del teatro comunitario tras la crisis del 2001: la catarsis de una sociedad}

Dijimos con anterioridad, que el sentido que impregna este teatro, como manifestación de la comunidad y para la comunidad, hace que no se atesoren los conocimientos sino que se compartan con gran apertura.

Ricardo Talento nos explica cómo se lleva a cabo esta labor de divulgación y puesta en marcha de otros grupos:

"Mucha gente tiene interés y quiere saber cómo es esto, cómo se hace. Hasta ahora, vamos con Adhemar a donde nos convocan. A partir de que hay un interés en una comunidad, como somos referentes de lo que es el teatro comunitario, nos llaman. Vamos, trabajamos, formamos gente porque la idea es armar algo, y que luego la gente del lugar se haga cargo y sigan funcionando. Luego continuamos conectados, nos reunimos una vez por mes todos los grupos. Ahí vemos nuestras necesidades, nuestros problemas. El trabajo en red es muy importante porque, en definitiva, esa es la gran ayuda que uno puede dar: retransmitir experiencias, ver que pasa en los grupos, cómo se puede solucionar problemas"

Y de este modo, con la experiencia de La Boca y Barracas como punto de partida, otros barrios generaron sus proyectos. Flores, Floresta, Boedo, Mataderos y Parque Patricios, etc... pusieron en marcha su agrupación. También en La Plata y en otras provincias como Misiones y Catamarca crecieron hilos de esta red. Dentro de la provincia de Buenos Aires, la ciudad de 9 de Julio es un ejemplo paradigmático.Nada mejor para ello, que darle la palabra a Adhemar Bianchi, la persona que inició esta modalidad y el "entusiasmador" -como él mismo se define- de esta forma de teatro quien nos hizo una relación puntual de la expansión de la misma:

"A veces hay bisagras en la historia, que hacen que los procesos se aceleren o se agranden. Con el tema del teatro barrial o comunitario, veníamos trabajando con algunos grupos desde hace tiempo: el Circuito Barracas, con Talento (Ricardo) y Los Calandracas, luego Misiones con el Grupo de la Estación, que hace 5 años que comenzaron y el Grupo Oberá, hace tres años, pero digamos que el año 2001 y la crisis política, trajo un resurgimiento de la participación popular por intermedio de las Asambleas Populares, y la gente buscó canales de participación.

$Y$ siendo el teatro un canal de participación no contaminado, explotó. El desánimo que existe con los partidos políticos, con las organizaciones y con toda la parte tradicional de la actividad social, hizo que muchos vecinos trataran de empezar a entender su propia historia, la historia de su barrio y los por qué de muchas cosas.

En el tema de la memoria, comenzaron a plantearse que el teatro era una buena herramienta para la fiesta popular, para que los barrios no fueran sólo dormitorios sino que fueran un lugar que recuperara su vida social, su vida colectiva, su vida comunitaria.

$Y$ en ese plano se fueron acercando distintos grupos de gentes, de distintos barrios, y entonces junto con Ricardo Talento, fuimos en alguna medida contando nuestra experiencia como para entusiasmarlos. Nosotros decimos que somos entusiasmadores. 
$Y$ ahí surgió el primer grupo: "Mataderos" en el barrio del mismo nombre, a partir de una función de "Venimos de muy lejos".

Cuando terminó la función, invitamos al público a conversar y le contamos cómo lo hicimos, le dijimos que evidentemente ellos también lo podían hacer, y bueno... iSe hizo! Surgió un grupo ahí, que ya está en su tercer año de trayectoria, con dos producciones; un grupo realmente muy interesante en el barrio de Mataderos, que trabajaron primero sobre su barrio y luego sobre una historia que tiene que ver con el ganado, con la historia de la carne -una historia muy argentina- y también con la historia política de la Argentina, una obra con cincuenta vecinos, muy interesante.

Se formó luego otro grupo: "Patricios" en el barrio de Patricios, y otro en Pompeya, que están los dos trabajando. Uno en el parque y el otro en una plaza en Patricios, ya con espectáculos preparados.

Se formó un grupo en Flores, que trabajó con la historia de una plaza a la que le habían tratado de instalar un shopping, y los vecinos salieron a defenderla. Esa fue una historia y ahora ya entran en una segunda historia.

Se formó un grupo en Boedo que ya venía trabajando; nos pusimos en contacto, pero ellos ya venían contando la historia de Boedo, también desde 2001.

Después en la zona de Caballito, se hizo un trabajo de radio, con las canciones de la resistencia en el mundo, llamado "De vecinos que una radio llamó" y ahora están por estrenar una segunda parte de su espectáculo, también muy lindo.

Después lo más interesante que se formó, en términos de cómo un pueblo revivió, es: "Patricios, 9 de Julio", en un pueblo de la Provincia de Buenos Aires, cerca de 9 de julio. Eran seis mil habitantes que, cuando sacaron el tren - unos de esos disparates que se han hecho acá- ese pueblo se diezmó, quedó con quinientos habitantes, y dos personas que vivían allí vieron nuestro espectáculo, se entusiasmaron, fueron a un seminario nuestro y nos plantearon que fuéramos a su pueblo a contar lo nuestro. Fuimos y ese pueblo, a partir de contar la historia de esa estación de trenes, su propia historia, empezó a resurgir por medio del turismo rural y por el lado de acontecimientos culturales una vez por mes; y han conseguido apoyo (que nunca conseguían de parte de los políticos). Ahora fue el intendente de 9 de Julio, y reciben alguna ayuda, y hasta han hecho el carnaval. De más está decir que ahora salen otros pueblos, con diferentes espectáculos.

Estamos dando seminarios en La Plata con la Comisión de la Memoria y se ha formado un grupo allí, que son los "Dardos de Rocha".

En Ramos Mejía estamos conformando un grupo. En Ituzaingó se conformó otro grupo también. Y ahora también en Reconquista, Santa Fe.

Muchos funcionan en estaciones de ferrocarril abandonadas, como reivindicación.

En general, el tema de los ferrocarriles está muy presente en los pueblos, porque el ferrocarril fue el espacio público y es uno de los espacios que está desactivado, que se puede trabajar, y que la gente siente como propio.

Eso pasó en Misiones, pasó en Patricios y ahora en Reconquista, digamos tres estaciones. Y bueno, estamos dando innumerable cantidad de seminarios que nos piden de distintos barrios, por ejemplo San Telmo..., también algunas organizaciones sociales como Barrios de Pie, gente que trabaja con niños como "Pelota de trapo" en el Hospital Argerich, o gente que trabaja con el deporte como "Defensores del Chaco en Moreno", que son Asociaciones Sociales que nos han planteado, ver qué línea de lo cultural y de lo teatral pueden agarrar.

Estamos trabajando con ellos, apoyándolos, o sea que se está conformando una red de Arte y Transformación Social. Hay gente que viene de la danza como "Crear vale la pena" que de la danza y de la música - pasando por muchas otras cosas- están trabajando en los barrios pobres de la zona norte, en la Cava, Boulogne..., que tienen centros culturales para la promoción de jóvenes por el lado del arte.

Está "Timbal", un grupo musical que empezaron a hacer trabajos en Moreno y toda la zona del oeste, y realmente vienen trabajando muy bien, armando aguantes culturales con otras organizaciones; es decir, evidentemente hay una necesidad de buscar formas alternativas de comunicación y de redes, y el Catalinas, que para nosotros lleva veinte años, en estos dos últimos años hemos visto una multiplicación impresionante de trabajo. 
Ricardo Talento hace repaso también de otros grupos fuera de la ciudad:

"En la provincia de Misiones son y a tres los grupos: de Posadas "La murga de la estación”, de Oberá "La murga del monte", de El Dorado "La murga del tomate”. Fue un encuentro de cuatro días, pusieron gradas, cuatrocientas sillas, estaba repleto, gente de pie, sentada en el suelo. Veo eso y digo: más allá del encuentro, esto hay que seguir haciéndolo, aunque no se programe un encuentro, que vengan elencos. ¡Esta ciudad en cuatro días movió cuatro mil y pico de personas! Sólo vi teatro comunitario, ipero qué potencia tiene! "La murga del tomate” nació de un grupo de ingenieros agrónomos, que estudiaban el tema de los transgénicos y empezaron a difundirlo a través del teatro, y ahora están trabajando con chicos en situación de riesgo que se agregaron al grupo. Empezaron con una cosa y se convirtieron en un grupo de teatro comunitario. Además en este encuentro hicieron algo que acá es muy difícil de hacer, el sábado se juntaron los tres grupos y presentaron un espectáculo en conjunto, donde ensamblaron sus obras y armaron un tercer espectáculo. Esta obra hablaba sobre la inmigración en Misiones. En Posadas hay teatro, pero el clásico teatro a donde van veinte personas y sin embargo para ver al grupo "La murga de la estación" había cola de 700 u 800 personas. Está muy metido en la comunidad éste tipo de teatro.

En La Plata hay dos grupos, uno es "Los ocupa del andén” que nació en la estación abandonada del ferrocarril provincial, y el otro es "Los dardos de Rocha”, que surge a consecuencia de un seminario que dimos con Adhemar (Bianchi) en la Comisión de la Memoria; se armó un grupo muy fuerte que habla sobre La Plata y su identidad. También el año pasado, se armaron grupos en Ramos Mejía, Ituzaingó, Villa Urquiza, bueno, hay veinticinco grupos en este momento", nos contaba en julio de $2004^{116 ” .}$.

La sorpresa es llamativa cuando nos dimos cuenta de que, a pesar de seguir un modelo, cada grupo está impregnado de las particularidades de su barrio o del colectivo que lo integra:

"En la escena del retablo, las vacas deliberan sobre cuál es la medida de fuerza que debe tomar un pueblo oprimido, y deciden hacer una huelga de hambre para evitar ser vendidas. De ese modo, actúan contra los intereses de los vendedores", sostiene Enrique Papatino, director del grupo de Mataderos, y revela así, que el imaginario de ese barrio, aflora en cada detalle ${ }^{117}$.

El proyecto que se lleva a cabo en el Hospital Argerich, Los Argerichos, coordinado por Cristina Paravano y Lázaro Teper (integrantes de Catalinas) también tiene su identidad específica, ya que está formado por personal del hospital (médicos, personal de mantenimiento, bioquímicos, visitadores médicos, técnicos, enfermeros y pacientes ambulatorios.). Comenzó a funcionar en marzo de 2004, y su primer montaje de creación colectiva: "Escenas de la vida hospitalaria" cuenta la historia del "Mesón de Turnos" y los avatares de quienes quieren ser atendidos, así Cristina Paravano nos expone:

"En este momento estoy coordinando un grupo de Teatro Comunitario Hospitalario, que dirijo yo, en el Hospital Argerich; es una experiencia muy interesante, muy linda, con pacientes ambulatorios, médicos, técnicos y ahora estamos encarando una especie de reflexión crítica sobre la situación hospitalaria, a través de anécdotas y cosas que pasan habitualmente, como las colas que tienen que hacer para sacar turno, del comportamiento de los administrativos, pero a su vez de la desgracia de éstos que tienen que soportar esas hordas de gente que los hostiliza, ya

116 Ibídem: Entrevista realizada por mí al director de teatro Ricardo Talento, en el Centro Cultural Barracas, Buenos Aires, el 3 de julio de 2004.

117 Entrevista realizada por mí a Enrique Papatino, en la Plaza de los Dos Congresos en Buenos Aires, tras la actuación del Grupo Res o no Res, el 3 de diciembre de 2004. 
que los hospitales no tienen capacidad para atender a tantos..,en fin, es muy interesante, estamos muy entretenidos con eso, con Lázaro Teper, que es otro integrante de Catalinas ${ }^{118}$ "

María. Florencia Calvosa Martín ${ }^{119}$ encargada de prensa del Grupo de Teatro Comunitario de Pompeya, nos cuenta sobre su trayectoria:

"El grupo se creó en Agosto de 2003 y fue idea de su director: Gabriel Galíndez; en sus inicios lo integraban 18 personas y comenzamos a reunirnos en Avenida Rabanal y Avenida Del Barco Centenera, un boulevard, ya que Pompeya no cuenta con ninguna plaza acorde para hacer teatro comunitario, lo que siempre ha sido una de las principales dificultades: el espacio, y la falta de instrumentos musicales y personas que los utilicen.

Nuestro primer montaje fue el 6 de diciembre de 2003, cuando representamos la obra "Intento de Casorio" y estamos preparando otra nueva; el grupo en ese momento ya contaba con 30 personas y modificamos el espacio de trabajo y nos trasladamos a Homero Manzi y Tabaré, que son calles con muy poco tránsito y en la esquina hay un centro cultural del barrio de Pompeya y un Museo con la Historia de Homero Manzi (Músico y autor de importantes tangos) que nos apoya. Pero lo principal es la colaboración que existe entre los miembros del grupo, ya que siendo un Grupo de Teatro comunitario, las labores las desempeñan todos, habiendo creado distintas comisiones (escenografía, producción, música y canto, vestuario, entre otras). Somos 33 personas, entre los 12 y los 50 años, no hay niños, la mayoría de la gente está entre los 16 a 25 . Ensayamos los miércoles y sábados(cuando no hacemos función)”.

Edith Scher ${ }^{120}$ directora del Grupo de Teatro Comunitario Mate Murga nos cuenta como surgió su grupo:

"El grupo se creó el 18 de agosto de 2002. Soy periodista y columnista de teatro, de un programa de radio que se llama Mate amargo. Simplemente le propuse a sus conductores (locutores) crear una murga con los oyentes. La convocatoria se hizo a través de la radio, y respondieron alrededor de 20 personas. Nuestras principales dificultades fueron no tener lugar propio, no contar aún con recursos económicos para equiparnos y comprar más instrumentos, etc. En la actualidad ensayamos los domingos por la tarde, en un galpón que el gobierno de la ciudad otorgó a Mate Amargo, en Gascón 112 (alli estrenaremos, pero no actuaremos exclusivamente allí) y los martes en mi domicilio particular. Estamos por estrenar nuestro primer espectáculo, del cual ya hicimos muestras parciales. Además, como éste está sustentado en canciones, hemos actuado en muchas oportunidades cantando solamente. Ahora el grupo lo formamos 30 adultos y 3 niños, de todas las edades"

Una experiencia interesante dentro de estos grupos, la constituye la que ya dimos a conocer, al analizar el efecto de la desaparición del ferrocarril y los pueblos fantasmas: la del Grupo de Teatro Comunitario Patricios Unidos de Píe, en la localidad bonaerense de 9 de julio, cuya creación y puesta en marcha ha constituido un elemento de revitalización cultural y socioeconómica para la maltrecha localidad; o el de Boedo Antiguo, con una apuesta clara de inmersión

118 Ibídem: Cristina Paravano, nacida en Buenos Aires (Capital Federal) el 18 de octubre de 1947, miembro del Grupo Catalinas Sur desde sus orígenes y directora del Grupo de Teatro comunitario del Hospital Argerich , que cada viernes a las 18 horas ensaya en el consultorio 46 de Cardiología, en la planta baja de dicho Hospital y que ya ha puesto en escena su espectáculo Entrevista realizada por mí, el 16 de agosto de 2004 en los camerinos del Galpón de Catalinas, en Buenos Aires.

119 Ibídem: Entrevista realizada por mí a María Florencia Calvosa Martín, responsable de prensa del grupo de teatro comunitario de Pompeya en el Centro Cultural Homero Manzi de Buenos Aires, el día 4 de agosto de 2004.

120 Ibídem: Entrevista realizada por mí a Edith Scher directora del grupo Mate murga, en el Círculo Cultural Barracas en Buenos Aires, donde ensaya en ocasiones el grupo, el día 7 de agosto de 2004. 
en las raíces del barrio del mismo nombre. Todos estos grupos, cada uno con su singularidad, son respuestas que sorprenden por la fuerza, el entusiasmo y el compromiso ético con que han surgido, en momentos tan desfavorables económicamente para el país.

\section{TEATRO COMUNITARIO EN BUENOS AIRES Y LA PROVINCIA 2004 $4^{121}$}

\begin{tabular}{|c|c|c|c|}
\hline Barrio & Nombre del grupo & Director & Dirección \\
\hline La Boca & Grupo de Teatro Catalinas Sur & Adhemar Bianchi & Benito Pérez Galdós 93 \\
\hline Barracas & $\begin{array}{l}\text { El teatro Barracas } \\
\text { (Circuito Cultural Barracas) }\end{array}$ & Ricardo Talento & Av. Iriarte 2165 \\
\hline Mataderos & $\begin{array}{l}\text { Grupo de Teatro comunitario } \\
\text { de Mataderos "Res o no res" }\end{array}$ & Enrique Papatino & $\begin{array}{l}\text { Parque Alberdi } \\
\text { Polideportivo Nueva Chicago }\end{array}$ \\
\hline Parque Patricios & $\begin{array}{l}\text { Grupo de Teatro comunitario } \\
\text { de Parque Patricios }\end{array}$ & Agustina Ruiz Barrea & $\begin{array}{l}\text { Av. Caseros y Pepirí Parque de } \\
\text { los Patricios }\end{array}$ \\
\hline Boedo & $\begin{array}{l}\text { Grupo de Teatro comunitario } \\
\text { Boedo Antiguo }\end{array}$ & Hernán Peña & Centro Cultural Julian Centella \\
\hline Flores & $\begin{array}{l}\text { Grupo de Teatro Alma Mater } \\
\text { de Flores }\end{array}$ & $\begin{array}{l}\text { Ana Laura Kleiner } \\
\text { y Alejandro Schaab }\end{array}$ & $\begin{array}{l}\text { Plaza de los Periodistas } \\
\text { Si llueve: Club } 25 \text { de Mayo, } \\
\text { Cesar Díaz } 3550\end{array}$ \\
\hline Floresta & $\begin{array}{l}\text { Grupo de Teatro comunitario } \\
\text { de Floresta }\end{array}$ & Orlando Santos & Plaza Monte Castro \\
\hline Pompeya & $\begin{array}{l}\text { Grupo de Teatro comunitario } \\
\text { de Pompeya }\end{array}$ & Gabriel Galíndez & Centenera y Tabaré \\
\hline Patricios 9 de Julio & $\begin{array}{l}\text { Grupo de Teatro comunitario } \\
\text { "Patricios Unidos de Pie " }\end{array}$ & Alejandra Arosteguy & Estación de Tren \\
\hline Caballito & $\begin{array}{l}\text { Grupo de Teatro comunitario } \\
\text { Matemurga }\end{array}$ & Edith Scher & $\begin{array}{l}\text { Centro Cultural Matrix } \\
\text { Entre Ríos } 1250\end{array}$ \\
\hline La Boca & $\begin{array}{l}\text { Grupo de Teatro comunitario } \\
\text { del Hospital Argerich }\end{array}$ & Cristina Paravano & $\begin{array}{l}\text { Viernes } 18 \text { horas. } \\
\text { Planta baja Consultorio } \\
46 \text { de Cardiología }\end{array}$ \\
\hline Ituzaingó & $\begin{array}{l}\text { Grupo de Teatro Ituzaingó } \\
\text { Laburartistas }\end{array}$ & Carlos Goyanes & $\begin{array}{l}\text { Instituto de Estudios Políticos } \\
\text { y Sociales }\end{array}$ \\
\hline Avellaneda & $\begin{array}{l}\text { Grupo de Teatro Comunitario } \\
\text { Pelota de Trapo }\end{array}$ & Catalina Highton & $\begin{array}{l}\text { Casa de los Niños } \\
\text { de Avellaneda, Santa Fe } \\
1522 \text {, Avellaneda. }\end{array}$ \\
\hline La Boca & $\begin{array}{l}\text { Grupo de la Boca Asociación } \\
\text { de Maquinistas Navales }\end{array}$ & $\begin{array}{l}\text { Andrea Salvernini } \\
\text { o Pablo Bocchicchio }\end{array}$ & $\begin{array}{l}\text { Blanes, esquina } \\
\text { Almirante Brown }\end{array}$ \\
\hline La Plata & $\begin{array}{l}\text { Grupo de Teatro } \\
\text { de "Los Dardos de Rocha" }\end{array}$ & Diego Aroza & Plaza Moreno, Frente Catedral \\
\hline Ramos Mejía & $\begin{array}{l}\text { Grupo de Teatro } \\
\text { de Ramos Mejía }\end{array}$ & Beatriz Romeo & Plaza Mitre \\
\hline
\end{tabular}

121 El numero de grupos sigue en aumento, aquí se consignan los que aparecían integrados en la red de teatros comunitarios, facilitada por el Circuito Cultural Barracas hasta julio de 2004. 
En medio de una crisis por la que el país se hunde en una depresión sin precedentes, el teatro popular con su estética de compromiso, se mantiene resistente y resiliente. Entendiendo la resiliencia, en el sentido empleado con anterioridad, como la capacidad de los creadores de construir sentido en la adversidad, de generar productividad en el dolor y de transformar la precariedad, en fuerza ideológica y estética. ${ }^{122}$

El compromiso social de Catalinas Sur es permanente. Fuertemente ligado a la responsabilidad de su ser social, ven, saben y no callan. Por lo tanto, no traicionan su ética. No se hacen los distraídos ni miran para otro lado, por el contrario, asumen una responsabilidad histórica.

La aparición de tantos colectivos de teatro, pensamos que responden a un intento de recuperar la identidad cultural del país, empezando por la de su barrio, la de su entorno, como un acto de resistencia cultural, frente a un mundo globalizado que tiende a borrar las diferencias culturales.

Por eso creemos que hacer hoy teatro en las circunstancias que vive el país, se convierte de por sí solo en un hecho político; porque es un acto de presencia, un acto estético que expresa la resistencia a la homogeneización, y busca desesperadamente las diferencias en la manifestación teatral como hecho ético.

122 Ibídem: DUBATTI, Jorge (coord): El nuevo teatro argentino de la postdictadura. Micropoéticas I, Centro Cultural de la Cooperación, Buenos Aires, 2002, pág 127. 